\title{
The Monetary Policy Committee's Reaction Function: An Exercise in Estimation
}

\author{
C.A.E. Goodhart ${ }^{1}$ \\ Financial Markets Group \\ London School of Economics \\ (May, 2004)
}

\section{Introduction}

Almost all economists know the story about the (drunk) person searching for his lost wallet in the night under the lamp-post, not because that was the most likely place to have dropped his wallet, but because that was where the light was. I shall argue here that this story is fitting in the case of Taylor-type Central Bank reaction functions. These functions indicate how Central Banks might adjust interest rates in response to deviations of current inflation and current output from some desired level, so that,

$$
i_{t}=a+b\left(\pi_{t}-\pi^{*}\right)+b_{2} y_{t}+b_{3} i_{t-1}
$$

where $\mathrm{i}$ is the nominal interest rate, $\pi$ the current rate of inflation, $\mathrm{y}$ is the estimated output gap, and the final term $\left(b_{3} i_{t-1}\right)$ is usually included to account for the empirical evidence of auto-correlation in the time path of interest rates, (Taylor, 1993, 1999).

In some respects, however, this formulation is distinctly odd. In particular, all the main empirical studies suggest that interest rates do not affect output significantly until after a lag of a few quarters, then building up into a hump-shaped response; and similarly do not affect inflation until a further delay, with a humped shape response following after that of output,

\footnotetext{
${ }^{1}$ My thanks are due to O. Aspachs for excellent research assistance.
} 
(see Woodford, 2003, Chapter 3; Christiano et al, 2001; Monetary Policy Committee, 1999).

That raises a question why the Central Bank decision makers should vary interest rates in reaction to current movements in variables which are unaffected by the Central Bank instrument, in the sense that they are believed to be almost totally unresponsive to such interest rate changes. Of course, Central Bank decision-makers in practice relate their interest decisions, not to current (and from the monetary policy view-point predetermined) variables, but to forecast values for future inflation and output, with a forward-looking interest rate reaction function of the form:-

$$
i_{t}=a+b_{1} E_{t}\left(\pi_{t+j}-\pi^{*}\right)+b_{2} E_{t}\left(y_{t+j}\right)
$$

see Bernanke and Woodford (1997), Clarida, Gali and Gertler (1998, 1999, 2000), King (2000), Bean (2003).

A problem facing those wishing to do applied empirical research is that data on the forecasts which formed an input into the interest rate decision are generally not available, or, if available, often without any indication of the prospective future interest rate path that was assumed for the purpose of completing that forecast. There are only a few examples of Central Banks releasing both an official authorised forecast, (rather than a 'staff' forecast, or several alternative forecasts), and a complementary projected path for interest rates. The Monetary Policy Committee (MPC) in the UK, especially since operational independence in 1997, and the Reserve Bank of New Zealand, are the only two of which I am familiar. This paper will concentrate on MPC UK data. 
One response to the claim that Central Bankers would not be so stupid as to vary interest rates in reaction to pre-determined variables, (and why should Central Bankers be less rational and forward-looking than other agents?), is that the current levels of inflation and the output gap are key predictors for future inflation (and output gaps). Indeed so, but there are several problems with that line of argument. First, the so-called reaction function is then not a behavioural relationship at all; it is a reduced form combination of some underlying preference function, together with a forecasting procedure for mapping current output and inflation into future output and inflation. It is far from clear that the underlying preferences can be recovered from this reduced-form combined function, and, like other such reduced form equations, it is subject to the Lucas critique.

Second, especially when estimating such a reaction function, (as equation 1) on its own, other variables, e.g. asset prices such as exchange rates or housing prices, may enter the equation significantly, but it then becomes difficult to discriminate whether this is because they enter the objective function itself, or whether they add to the ability to predict future inflation and output gaps, (for an exercise that aims to do just this, see Siklos, et al, (2004 a and b)).

The substance of this paper consists of running Taylor-type reaction functions against the MPC's forecasts for future inflation and output (at various horizons), as well as against current inflation and output. We shall use information, partly inside personal experience, as an ex-member of the MPC, partly publicly available, outside information, to indicate what was the underlying objective function of the MPC in the circumstances of the data period (1997-2003), (on this, also see Goodhart, 2004a), and then compare the results of running a Taylor function at the relevant forecast horizon with running exactly the same functional 
relationship at differing (in practice shorter) horizons, and when using contemporaneous data.

To give a taste of the results, the coefficients in this function change markedly (and highly significantly) as the (forecast) horizon alters, and, on the basis of this, admittedly very short data set, it would simply not have been possible to work out what the MPC was trying to do by running a conventional Taylor-type function using contemporaneous values alone.

The structure of this paper is as follows. In Section II we describe the data that we use. In Section III we report the results of the empirical exercises. We discuss some of the more initially puzzling aspects of these results in Section IV, which also concludes.

\section{The Data Base}

The main difficulty that we face is that the Bank of England only began publishing forecasts of future output growth (\% change over the similar quarter in the previous year) from Q3 1997, after the Chancellor of the Exchequer had delegated operational independence to the Bank of England in May 1997. It does not now, and never has, published explicit data for estimated output gaps.

So, we face two drawbacks in our data set. First, we have a short observation period as our sample, quarterly from 1997 Q3 to 2003 Q3. Second, we cannot test, at least not from published data, a Taylor-type reaction function directly, only a simulacrum with the output 


$$
-5-
$$

gap replaced by output growth. While this is forced upon us by data availability, there will obviously be a relationship between these two variables, especially when deviations of output from perceived equilibrium have been slight. Figure 1 here reproduces Figure 3, p. 20, of Sauer and Sturm, (2003), who write, p. 19,

\begin{abstract}
"Among economic forecasters, the distinction between "classical business cycles", i.e. fluctuations in actual production levels, "growth cycles", i.e. fluctuations in deviations of production from its trend and "growth-rate cycles", i.e. fluctuations in production growth, is well known and explained by, e.g. Nierhaus and Sturm (2003). Figure 3 illustrates the basic idea for the latter two. The lower panel clearly shows that growth and growth-rate cycles are not identical in measuring turning points. In particular, the turning points of growth-rate cycles exhibit a clear lead in comparison to the turning points of growth cycles. Hence, the use of production growth rates instead of deviations of production from its trend - introduces a forward-looking perspective with respect to the business cycle into the analysis.....
\end{abstract}

Apart from divergent sample periods, this difference in business cycle measures might explain why Fourçans and Vranceanu (2002) report considerably higher g $\pi$ and lower gy estimates as compared to our results.....; Fourçans and Vranceanu (2002) take annual growth of industrial production instead of an output gap measure - as used by all others - to assess the stance of the business cycle."

In practice, however, the output growth measure, as used here, involves comparing current output with output in the same quarter a year ago, whereas output gaps are usually measured on a contemporaneous basis. That reduces the lead of the output growth measure. In any case, as will be seen in Section III, the empirical results from using output growth data are highly significant and have a clear explanation.

The second difficulty is that the output data, of ex post actuals, are subject to continuous revision over a considerable number of subsequent years. Moreover in the last couple of decades the revisions have not been random in effect; for a variety of reasons the initial estimates have tended to be revised upwards over time (the first estimates have a downwards 
bias).

This causes a problem for forecasters, decision-makers and subsequent analysts. Do you, as a forecaster, try to forecast what the Office for National Statistics (ONS) will state what growth is as the forecast period develops, or what they will show some ten, or so, years later after subsequent revisions. Particularly since the bias is unknown and probably changing over time, since the ONS is continually trying to improve the date and to reduce the size of the bias, my own assumption, supported by some direct personal observation, is that the former is the case.

So I have tried to use initial, contemporary data on output growth. This has been facilitated by an exercise that the Bank has done, undertaken by Castle and Ellis, reported in their Quarterly Bulletin, (BEQB 2002), to provide on their website Excel sheets of contemporaneous estimates of output, available at www.bankofengland.co.uk/statistics/gdpdatabase. The output growth data, used here, are taken from that, until $2001 \mathrm{Q} 3$ when that data set ended; the remaining data are taken from ONS estimates prior to the revision in the Autumn of 2003.

The data for actual and forecast output growth are shown in Table 1, with the forecasts relating to a particular output date set out horizontally, thus the output growth in 2003 Q3 was estimated at $1.89 \%$, and its forecast a year earlier in $2002 \mathrm{Q} 3(\mathrm{t}+4)$ was $2.94 \%$, and in 2001 Q3 $(\mathrm{t}+8)$ was $2.11 \%$. Note that forecasts are completed in the middle of each quarter, (February, May, August, November), so the current quarter $(\mathrm{t}=0)$ also has to be forecast. 
By comparison, there are few problems with the data for inflation. Over this time period the inflation target was defined as achieving a target rate of $2.5 \%$ for a version of the Retail Price Index (RPI) which excluded the direct effects of interest rate changes, e.g. on mortgage interest payments, i.e. RPIX. The data for RPIX are collected by survey, and once obtained almost never revised. The series of forecasts for RPIX ( $\%$ change on the same quarter a year ago) are available back to 1993, though for our purposes we only use data from 1997 . These latter are shown in Table 2.

Unlike forecasts for the weather, or for other exogenous variables, the forecasts are made so that decision-makers can adjust their interest rate in order to influence the future evolution of both output and inflation. ${ }^{2}$ To be more precise the forecasts are made in the mid-quarter month, say February in Q1, using as an input into the forecast the level of interest rates established by the Monetary Policy Committee in the previous month, in our example in January. The forecast is then conducted on the basis of the conditioning assumption that interest rates are then held constant over the full forecast horizon of eight quarters. ${ }^{3}$ Then the MPC considers, e.g. at its February meeting, whether it is content with the consequential profiles for output and inflation. If not, it can review what effect an interest rate adjustment would have on these profiles. If the MPC does decide to make an adjustment to interest rates, say an increase of $2 \%$ in official short-term rates, then the profiles are reworked to

${ }^{2}$ I have seen papers, e.g. Klaeffling and Lopez (2003), in which it is proposed to use lead values of inflation and output to estimate a reaction function for current interest rates. Since current interest rate decisions affect future output and inflation, such a procedure is inadmissible.

${ }^{3}$ Longer forecasts, beyond the two year horizon, are carried out in the Bank on occasions. In such cases, in order to avoid Wicksellian instability, a Taylor-type reaction function is imposed after the two year horizon. 
show the consequence of interest rates being $2 \%$ higher (than in the initial forecast) throughout the forecast (until $t=8$ ), and this latter, reworked, forecast is what is then published in the immediately following Inflation Report.

This procedure of using a constant-interest-rate (CIR) conditioning assumption has been the subject of contention, having been both strongly attacked (Svensson, 2003; Martijn and Samiei, 1999, Meyer, 2001) and defended (Goodhart 2001 and 2004a). It is not the purpose of this paper to go over that ground again. It suffices here to note that this was the way the exercise was actually done.

The implication, however, is that the relevant forecast for influencing policy decisions is not the published forecast (in the Inflation Report) which shows the forecast ex post the interest rate decision, but the initial ex ante forecast (before the decision is taken) which is not published. It is, however, possible to construct a proxy for such ex ante forecasts. In 1999 the Monetary Policy Committee authorised a publication on 'The Transmission Mechanism of Monetary Policy', (largely prepared by the staff), showing diagrammatically on page 12 the effect of a $1 \%$ change in interest rates, maintained for one year and then reversed, on both output and inflation. I have translated, by eye, the modal value of the distributions shown in p. 12 (ibid) into numerical point forecasts.

For my purposes, however, I want a rule of thumb for a change in interest rates maintained over two years, until $t=8$, not just one. For inflation there is no problem, since the lags are so long that the results are equivalent. ${ }^{4}$ But for output, I have had to make an ad hoc

${ }^{4}$ The Bank of England has introduced a new quarterly model, (BEQM, see News 
assumption about the effect of the extra year's maintenance. Moreover, interest rate changes are not made only in the forecast (Inflation Report, IR) month, but in the two preceding months as well, (though the frequency of making such adjustments, for some fairly obvious reasons, is higher in the IR month than in the other (not IR) months). So we need to take account of these as well.

Be that as it may, the rule-of-thumb adjustments to be made to the forecasts for interest rate changes are shown in Table 3, and the actual historical changes in interest rates, and the resulting implied changes in the forecasts are shown in Tables 4 and 5 (for output growth and inflation). Note that a change in interest rates in say Q1 1999 will affect output in Q2 1999, Q3 1999, etc., so the way that we have set up the tables, the effects run diagonally downwards in Table 4 and Table 5.

Then to recreate the ex ante, initial forecasts, we simply add back Tables 4 and 5 to Tables 1 and 2, giving Tables 6 and 7. Again note that the interest rate decision in the forecast month

Release on April 22, 2004), in which the responses to interest rate changes of inflation (somewhat quicker) and of output (somewhat larger) are slightly different from those used in this paper. See the article on 'The new Bank of England Quarterly Model', accompanying the News Release, and available on its website, especially Charts 1 and 2, p. 5. 
relates to the ex ante forecast going diagonally down to the right. For ease of exposition we also rotate these Tables around to show the forecasts, for output and inflation, relating to each interest rate adjustment horizontally in Tables 8 and 9. We are now in a position to relate interest rate (changes) during this (short) period both to the ex ante forecasts and actuals for inflation and output growth, (and also to the ex post forecasts - for comparison - though this latter is a misspecification).

\section{The Empirical Results}

Since official interest rates are frequently left unchanged, and, when changed, are adjusted usually in steps of 25 basis points, or multiples thereof, there is a case for using two-stage probit analysis, e.g. how much do the explanatory variables have to alter to provoke a nonzero response, and, given a decision to react, how large will the change be. In practice, most empirical work on Central Bank reaction functions has used basic, straightforward OLS. Both to allow simple comparison, and owing to our woefully short data set, we have followed that same practice.

What we show in Table 10 is a series of regressions in which the level of interest rates is regressed against inflation and output growth at differing forecast horizons (and the current actual data) plus a constant and a lagged dependent variable. The results are striking.

The inflation forecast has an extremely large, and highly significant, coefficient at $\mathrm{t}=7$ and 8 , but this coefficient falls rapidly towards zero as the horizon shortens, being statistically insignificant from $t+5$ down to $t+0$, and with actual data. In contrast, the coefficient on 
output growth is insignificant at long horizons, $t+7$ and $t+8$. Then the coefficient rapidly increases both in (positive) size and in significance, reaching a maximum between $t+3$ and $t$ +5 . The coefficient is slightly smaller at $t+0$, and with actual data, but remains highly significant. The coefficient on the lagged dependent variable remains extremely close to unity, and well defined with small standard errors, from $t+8$ to $t+1$. At the shortest horizon, $\mathrm{t}+0$ and actuals, the coefficient drops below unity, and with the actuals, but never with the forecasts, the coefficient is, just, significantly different from unity.

With the coefficient on the lagged dependent variable being effectively at unity, this implies that the appropriate form of the regression should be in first difference form. Consequently the constant in the regression in levels should have, and does have, a zero coefficient, though rising to positive values at $\mathrm{t}+0$, and with the actuals.

The fit $\left(\mathrm{R}^{2}\right)$ remains virtually unchanged, around 0.92 at all horizons, and the DW ratio is close to 2 .

We then re-run the equation in first difference form, adding two lags of the prior quarterly change in interest rates, to test for possible gradualism, (on gradualism see Sack, 1998 and 2000; Sack and Wieland, 2000; Goodhart, 1999; Woodford 2003). The results are shown in Table 11. As expected, these results confirm those of the equation in levels. The coefficient on inflation is unchanged at $\mathrm{t}+8$ and $\mathrm{t}+7$, but then falls more gradually than in the levels version, remaining significant until $t+4$. The coefficient on output growth is again insignificant at the longest horizons, $\mathrm{t}+7, \mathrm{t}+8$; it is highly significant between $\mathrm{t}+2$ and $\mathrm{t}+$ 6 ; it is positive, but loses significance at the shortest horizons, $\mathrm{t}+0$ and actuals. Although 
the first lag of the change in interest rates is usually positive, it is never significant, and the second lag is negative throughout, though insignificant. Unlike the levels equation, the fit, for an equation in first differences, is extremely good at the longer horizons $t+7, t+8$; then falls to moderate levels at horizons from $t+6$ to $t+1$ (around 0.4 to 0.5 ), and then drops dramatically at the shortest horizons, $t+0$, actuals; one can note that it was at these shortest horizons that the lagged dependent variable diverged from unity, so a first difference format is misspecified.

Since the lagged changes in interest rates were not significant, we omitted them and re-ran the regressions, Table 12. The only additional point to note here is that both the fit and the DW ratio now decline even more at the short horizons.

Recall that we are running these regressions on our reconstruction of the ex ante forecast facing the MPC, that is the forecasts that they would have seen and published if they would have made no interest rate changes at all since the previous IR forecast. Put another way, we adjusted the ex post forecasts to add back our estimate of the effect of the interest rate change itself. What would happen to our regressions if we just run the regressions on the raw, ex post IR forecast data. This is shown in the exactly equivalent Tables 13, 14, 15.

In these regressions the coefficient on the inflation forecast is never significant, though usually positive in the first differenced format. The coefficient on output growth loses it prior significance between $t+3$ and $t+6$, but, with the adjustment factors for output being small at short horizons, the coefficients at $t+2$ and below remain unchanged. The lagged dependent variable in the levels equation still remains close to unity until short horizons. 
With these unadjusted data, both the value of $\mathrm{R}^{2}$ and DW fall in the levels equation at the longer horizons, making it appear that the shorter horizon runs fit the data better. In the first difference format, the steady decline in $\mathrm{R}^{2}$ from $\mathrm{t}+8$ to $\mathrm{t}+0$ is no longer apparent.

Assume that an observer only had access to current actual data; or to the actual ex post forecasts, but did not adjust for the effect of, (the interaction between), the interest rate changes themselves and the resulting ex post forecasts of output and inflation. What might he have deduced. First, there was no sign at all of the MPC reacting to inflation, (against orders!). Second, there was a large, and highly significant, response to current output growth, which is very much larger in the long run than in the short, given the lagged dependent variable coefficient of about 0.85 . Third, this same high, but less than unity, value of this coefficient suggests an interest rate smoothing procedure (gradualism).

Compare this mis-specified assessment with the results of, what I claim to be, the correct specification. Here the assessment of behaviour runs as follows: The MPC concentrates its focus on the ex ante forecast of inflation at $t+8$ and $t+7$ (n.b. the highest $R^{2}$ in the first difference format Tables 10 and 11), and changes interest rates enough to drive forecast inflation back into line with target. Note that the estimated adjustment factor for inflation at $\mathrm{t}+8$ is about 0.3 , i.e. a $1 \%$ change in interest rates affects inflation by $0.3 \%$ after two years. With our coefficient at $t+8$ equal to 2.3 , this suggests that any $1 \%$ deviation of forecast inflation from target is immediately offset by an $0.7 \%$ response from policy. Naturally, given this, almost totally offsetting and immediate, policy response, the ex post IR, unadjusted, forecasts show no residual relationship with inflation at all. Moreover, since it is assumed that interest rates do not affect inflation at horizons below $\mathrm{t}+4$, there should be no such 
response to short run and current data which are, in effect, totally irrelevant, bygone data in any case.

Because of the close links between inflation at $t+4$ and output growth at $t+0$, the finding of a close link between ex ante forecasts of inflation at $t+8, t+7$ and the current change in interest rates, becomes observationally similar to (though econometrically somewhat better than) a relationship between ex ante forecasts of output growth between about $t+3$ and $t+5$ and current changes in interest rates. Although the MPC is focussing (correctly) on predicted (ex ante) future inflation and, hence, output growth, auto-correlation between current and forecast output growth leads to a, purely statistical, relationship between current output growth and current interest rate changes. This, like several other aspects of the results using current data only, is a consequence of mis-specification.

Again the (correctly specified) forecast data show the coefficient of the lagged endogenous variable to be, as close as econometrics normally can get, exactly unity. As deviations between forecast and output occur, the MPC immediately changes interest rates by enough to drive forecast back into line with target. There is, therefore, no difference between short and long-run responses, no attempt at interest rate smoothing, no conscious gradualism at all! That these features show up in this data set, when using actual current data, is again simply the result of misspecification.

\section{Some Puzzles}

It is relatively rare to document a case where policy to control a variable, in this instance 
inflation, has been so successful that the ex post relationship between the target variable and the instrument becomes insignificant. Yet this is what we find here, see Tables 12, 13, 14. This possibility is well known in the literature, e.g. Tobin, 1970, Buiter, 1984, but there have been few attested examples. It does, however, raise the problem of why, and how, current inflation came to be so strongly significant in most prior tests of Taylor-type reaction functions using contemporaneous actuals, given that most of the time the achievement of price stability was the prime objective of the authorities.

The UK experience in the years of our sample, 1997-2003, was, however, remarkable for its success in stabilising inflation around its target level. The variance of actual inflation, as measured by RPIX, around the target of $2.5 \%$ was minuscule as measured either by historical standards, (see Benati, 2003), or compared to most other countries. Although there has been some systematic correlation in the deviation of actual inflation from target, it has been small enough to disregard. Outcomes have been less successful in previous periods, and perhaps in other countries. In so far as actual inflation deviates to a significant and worrying extent from target, pressures will build up on the authorities to respond, irrespective of the belief that only future inflation reacts to current interest rates. Moreover, given the autocorrelation in economies, current deviations of inflation from target may well indicate forecast, future deviations of inflation from target. Indeed, as noted in the Introduction, this is an argument for the use of such reaction functions. Thus, one seems to reach the rather odd conclusion that such reaction functions, using actual contemporaneous data, are effectively identified by their comparative failure to achieve their supposed objective.

The second problem that arises from these results is even more difficult. I interpret these 
results as implying that the MPC sought to offset, immediately and almost one-for-one, any emerging deviation of forecast inflation, (at its chosen horizon $t+7, t+8$ ) from target. There was absolutely no indication of gradualism, of short run response being much less than longrun responses, in these results. Yet simple observation of the time path of interest rates, Figure 2, reveals that the actual auto-correlation of interest rate changes, with a high ratio of continuations of small steps of the same sign relative to reversals has been just as high during the MPC years as before.

How come? This is a complicated and complex story, which is the subject of a separate paper (Goodhart 2004c). But let me give the gist of those findings here. Given the above econometric results, we dismiss those arguments (see Ellison, 2003; Goodhart, 1999; Sack, 1998; Sack and Wieland, 2000; Woodford, 2003)), that claim that gradualism may, of itself, be desirable, since this was not what the MPC was aiming to achieve. This auto-correlation of interest rates was not intended. Instead it came about primarily through two routes. One such mechanism, though from my analysis somewhat the less important, occurred as a direct consequence of using a constant interest rate (CIR) conditioning assumption in making the forecast. As it well known, holding nominal interest rates constant soon results in Wicksellian instability. So any trend developing at the horizon $t+8$ is likely to persist, and perhaps to become more extreme, beyond the horizon, as shown in Figure 3. Then rolling the forecast quarter by quarter could easily result in a series of small, similarly signed step changes. Since the Bank does not publish forecasts beyond the $t+8$ horizon, we cannot test this directly.

What we can try to do is to make use of the strong relationship between output growth and 
inflation a year later. What we do is to look at the relationship between forecast output growth between $t+4$ and $t+8$ in the ex post data in each IR and subsequent interest changes. The auxiliary hypothesis is that when high output growth is forecast in the second year in the IR, inflation after $t+8$ will also be expected to be above target (n.b. the relevant forecast here must be ex post as in the IR, not ex ante). Given this auxiliary forecast, only 5 changes in interest rates, out of 12 , which can be tested could have been due to this cause, in some part. The analysis and calibrations are shown in more detail in my comparison paper (Goodhart 2004c).

A second explanation of the sequential nature of the actual interest rate path, apparently exhibiting gradualism, is that there were auto-correlated errors in the Bank of England's forecasts of inflation and output. Earlier studies of the efficient market hypothesis for the short-term money market yield curve for the USA (Diebold and Li, 2003; Duffee, 2002; Carriero et al., 2003; and Rudebusch, 2002) and Japan (Thornton 2004) have suggested that there were systematic errors in forecasting the future time path of official interest rates. Rudebusch and $\mathrm{Wu}(2004)$ argue, p. 16, that,

"The persistence in $\mathrm{S}_{\mathrm{t}}$ [a slope factor capturing the cyclical response of the Fed] reflects the fact that the Fed adjusts the short rate promptly to various determinants output, inflation, and other influences in the residual $\mathrm{u}_{\mathrm{t}}$ - that are themselves quite persistent (e.g., $\left.\rho_{u}=.975\right)$. Thus, our estimate of $\rho_{S}$ decisively dismisses the interest rate smoothing or monetary policy inertia interpretation of the persistence in the short rate. The persistent deviations of slope from fitted slope..... occur not because the Fed was slow to react to output and inflation but because the Fed responds to a variety of persistent determinants beyond current output and inflation."

Whereas I agree that the MPC never consciously adopted gradualism, I suggest that the persistence was due to autocorrelated errors in forecasting future inflation and output, ${ }^{5}$ not to

${ }^{5}$ Such errors can also be due to failures to observe the correct current level of the 
the MPC responding to other [undefined] determinants. Indeed reacting to determinants other than the forecast for RPIX would have been contrary to the MPC's mandate. Thus errors in forecasting the official time path of interest rates may in turn have been due to systematic errors by Bank, and other, forecasters in predicting the future course of output and inflation. All this is set out in more detail in my companion papers, (Goodhart $2004 \mathrm{~b}$ and c), where the role of forecast errors in driving the auto-correlated time path of interest rates is discussed in detail.

\section{Conclusion}

All the results of this work need to subject to the qualification that the time period, and hence sample size, is short. Nevertheless we have attempted to establish that the MPC responded aggressively to any deviation of ex ante forecast inflation from its target, so much so, and so successfully, that there is no residual significant relationship between ex post inflation at any horizon, from current actual to $t+8$, and nominal interest rates in this period. It would not have been possible for an observer to deduce what the MPC was really doing if she was to run a Taylor-type reaction function using current actual data during this short period. We hypothesize that the success of prior empirical tests of finding significant effects of current inflation on nominal interest rates has been because inflation targeting was either not being attempted so wholeheartedly, or just less successfully. Be that as it may, it does call into question the whole exercise of attempting to identify how Central Banks may react to a complete set of current and future variables by a simple regression using only current 
variables.

An even more complex problem arises because these results indicate that the MPC did not intend to build gradualism into its own behaviour, and yet gradualism in the shape of consecutive series of similarly signed small steps in interest rates occurred nonetheless. Our attempts to explain this conundrum are mostly to be found in two separate, but connected, papers (Goodhart $2004 \mathrm{~b}$ and c). Even so, we suggest that such (largely unintended) gradualism arose through two main routes, first - and probably less important - as a quasiautomatic effect of using the constant-interest-rate conditioning assumption for the forecast, and second as a result of strong auto-correlation in forecasting errors.

\section{Bibliography}

Bank of England, (2004), 'The new Bank of England Quarterly Model', April, http://www.bankofengland.co.uk/mpc/qtlymodel.pdf.

Bean, C., (2003), `Asset Prices, Financial Imbalances and Monetary Policy: Are Inflation Targets Enough?', presented at BIS Conference on Monetary Stability, Financial Stability and the Business Cycle, Basel, Switzerland.

Benati, L., (2003), ‘Evolving Post-World War II UK Economic Performance', Bank of England Working Paper, July.

Bernanke, B.S. and M. Woodford, (1997), 'Inflation Forecasts and Monetary Policy', Journal of Money, Credit and Banking 24: 653-684.

Buiter, W.H., (1984), 'Granger-Causality and Policy Effectiveness' Economica, 51, (202), May: 151-62.

Carriero, A., Favero, C.A. and I. Kaminska, 'Financial Factors, Macroeconomic Information and the Expectations Theory of the Term Structure of Interest Rates', unpublished manuscript, (2003).

Castle, J. and C. Ellis, (2002), 'Building a real-time database for GDP(E)', Bank of England Quarterly Bulletin, 42, (1): 42-9. 
Christiano, L.J., Eichenbaum, M.S. and C.L. Evans, (2001), 'Nominal Rigidities and the Dynamic Effects of a Shock to Monetary Policy', NBER Working Paper No. 8403, July.

Clarida, R., J. Galí and M. Gertler, (1998), `Monetary Policy Rules in Practise: Some International Evidence', European Economic Review, 42, 1033-1067.

Clarida, R., J. Galí and M. Gertler, (1999), ’The Science of Monetary Policy: A New Keynesian Perspective', Journal of Economic Literature, 37(4), 1661-1707.

Clarida, R., J. Galí and M. Gertler, (2000), 'Monetary Policy Rules and Macroeconomic Stability: evidence and some theory', Quarterly Journal of Economics, 115, 147-180.

Diebold, F.X. and C. Li, 'Forecasting the Term Structure of Government Bond Yields', NBER working paper 10048, (October 2003).

Duffee, G.R., 'Term Premia and Interest Rate Forecasts in Affine Models', Journal of Finance, (February 2002), 405-443.

Ellison, M., (2003), 'The Learning Cost of Interest Rate Reversals', Centre for Economic Policy Research (CEPR), Discussion Paper No. 4135, December.

Fourçans, A. and R. Vranceanu, (2002), 'ECB Monetary Policy Rule: Some Theory and Empirical Evidence', ESSEC Working Paper No. 02008, (forthcoming in: European Journal of Political Economy).

Goodhart, C.A.E., (1999), 'Central Bankers and Uncertainty', Keynes Lecture in Economics, 29 October 1998, reprinted in Proceedings of the British Academy, 101, pp 229-271.

Goodhart, C.A.E., (2001), 'Monetary Transmission Lags and the Formulation of the Policy Decision on Interest Rates', Federal Reserve Bank of St Louis Review, 83 (4) (July/August), 165-181.

Goodhart, C.A.E., (2004a), 'What is the Monetary Policy Committee Attempting to Achieve?', paper presented at the Conference in Honour of C. Freedman, at the Bank of Canada, Ottawa, June 19/20, (2003) forthcoming in published proceedings 2004.

Goodhart, C.A.E., (2004b), 'The Interaction between Bank of England Forecasting and Policy: An attempt at measurement', Financial Markets Group, London School of Economics, Discussion Paper No. [xxx].

Goodhart, C.A.E., (2004c), 'Gradualism in the Adjustment of Official Interest Rates: Some Partial Explanations', paper prepared for volume in honour of Basil J. Moore, forthcoming 2005.

King, M.A., (2000), 'Monetary Policy: Theory in Practice', address to the joint luncheon of the American Economic Association and the American Finance Association, Boston Marriott Hotel, 7 January 2000. See Bank of England website, 
http://194.129.36.50/speeches/speech67.htm.

Klaeffling, M. and V. Lopez Perez, (2003), 'Inflation Targets and the Liquidity Trap', ECB Working Paper No. 272, September.

Martijn, J.K. and H. Samiei, (1999), 'Central Bank Independence and the Conduct of Monetary Policy in the United Kingdom', International Monetary Fund, Working Paper 99/170.

Meyer, L.H., (2001), 'Comment', Federal Reserve Bank of St. Louis Review, July/August: 183-6.

Monetary Policy Committee, Bank of England, (1999), 'The Transmission Mechanism of Monetary Policy', Pamphlet, (Bank of England).

Nierhaus, W. and J.-E. Sturm, (2003), 'Methoden der Konjunkturprognose', Ifo Schnelldienst 56(4), 7-23.

Orphanides, A., (2001), 'Monetary policy rules based on real-time data', American Economic Review, 91: 964-85.

Rich, G., (2003), 'European Monetary Policy: Can the ECB learn from the Fed?', paper initially presented to the December 2, 2003, meeting of the EMU Monitor.

Rudebusch, G.D., 'Term Structure Evidence on Interest Rate Smoothing and Monetary Policy Inertia', Journal of Monetary Economics, (September 2002), 1161-1187.

Rudebusch, G.D. and T. Wu, (2004), 'A Macro-Finance Model of the Term Structure, Monetary Policy and the Economy', paper presented at the Federal Reserve Bank of San Francisco Conference on 'Interest Rates and Monetary Policy', March 19-20.

Sack, B., (1998), 'Uncertainty, Learning and Gradual Monetary Policy', Finance and Economics Discussion Series, Board of Governors of the Federal Reserve System, July.

Sack, B., (2000), 'Does the Fed Act Gradually?', A VAR Analysis', Journal of Monetary Economics, 46, 229-56.

Sack, B. and V. Wieland, (2000), 'Interest-Rate Smoothing and Optimal Monetary Policy: A Review of Recent Empirical Evidence', Journal of Economics and Business 52, 205-28.

Sauer, S. and J.-E. Sturm, (2003), 'Using Taylor Rules to Understand ECB Monetary Policy', CESifo Working Paper No. 1110, December.

Siklos, P.L., Werner, T. and M.T. Bohl, (2004a), `Asset Prices in Taylor Rules: Specification, Estimation and Policy Implications for the ECB', draft working paper, www.wlu.ca/ wwwsbe/faculty/psiklos/home.htm, April.

Siklos, P.L., Werner, T. and M.T. Bohl, (2004b), `Are Inflation Targeting Central Banks 
Relatively More Forward Looking?' working paper, Wilfrid Laurier University, May.

Svensson, L.E.O., (2003), 'The Inflation Forecast and the Loss Function=, Chapter 4 in Central Banking, Monetary Theory and Practice, ed. P. Mizen, (Cheltenham, U.K.: Edward Elgar).

Taylor, J.B., (1993), 'Discretion versus policy rules in practice', Carnegie-Rochester Conference Series on Public Policy 39: 195-214.

Taylor, J.B., ed., (1999), Monetary Policy Rules, (Chicago: University of Chicago Press).

Thornton, D., (2004), 'Testing the Expectations Hypothesis: Some new evidence for Japan', Bank of Japan, Institute for Monetary and Economic Studies, Discussion Paper No. 2004-E3, February.

Tobin, J., (1970), 'Money and Income: post hoc ergo propter hoc', Quarterly Journal of Economics, 84, (May), 301-17.

Woodford, M., (2003), Interest and Prices, (Princeton, N.J.: Princeton University Press). 
The Monetary Policy Committee's Reaction Function: Figures and Tables 
Figure 1

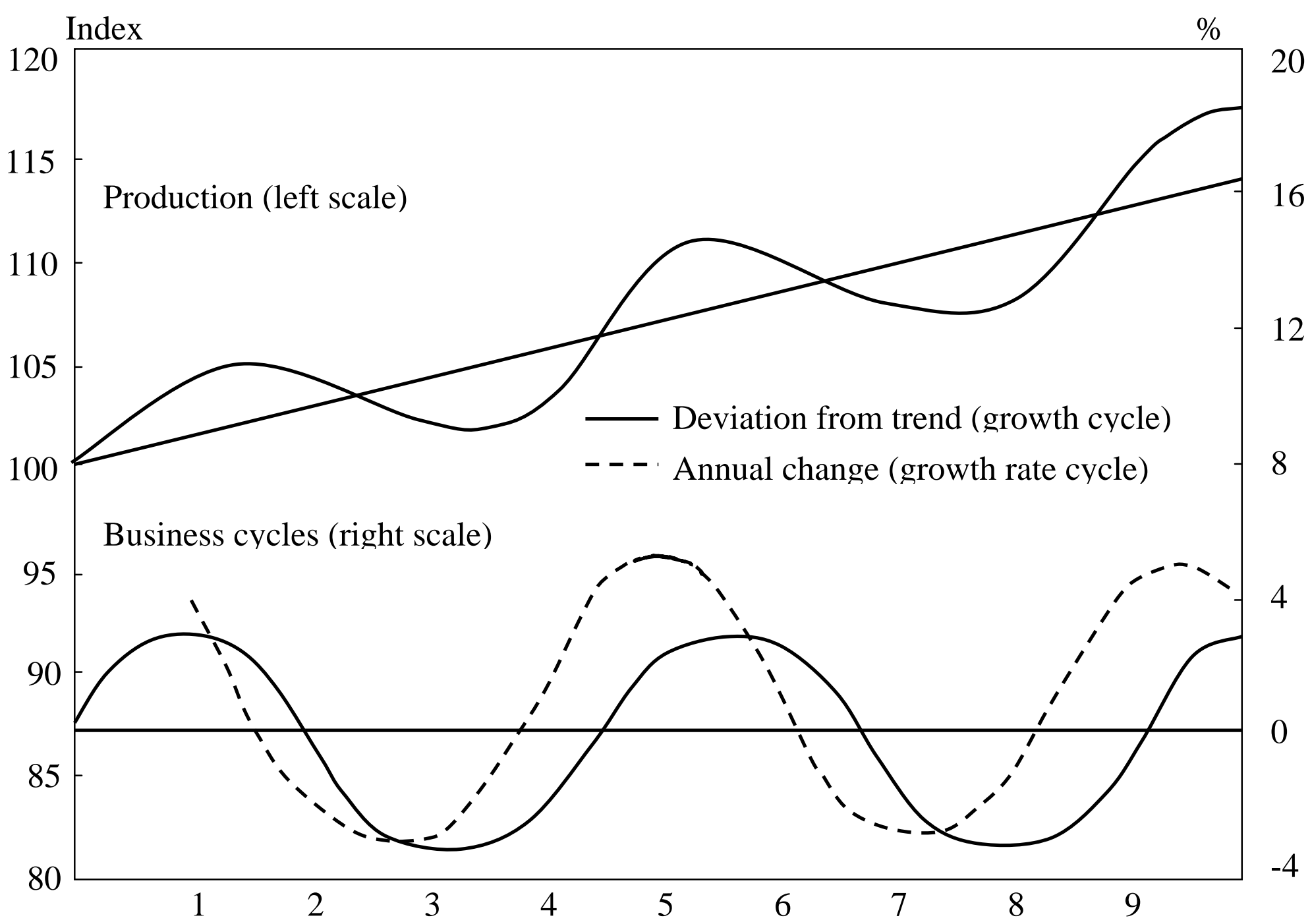


Figure 2

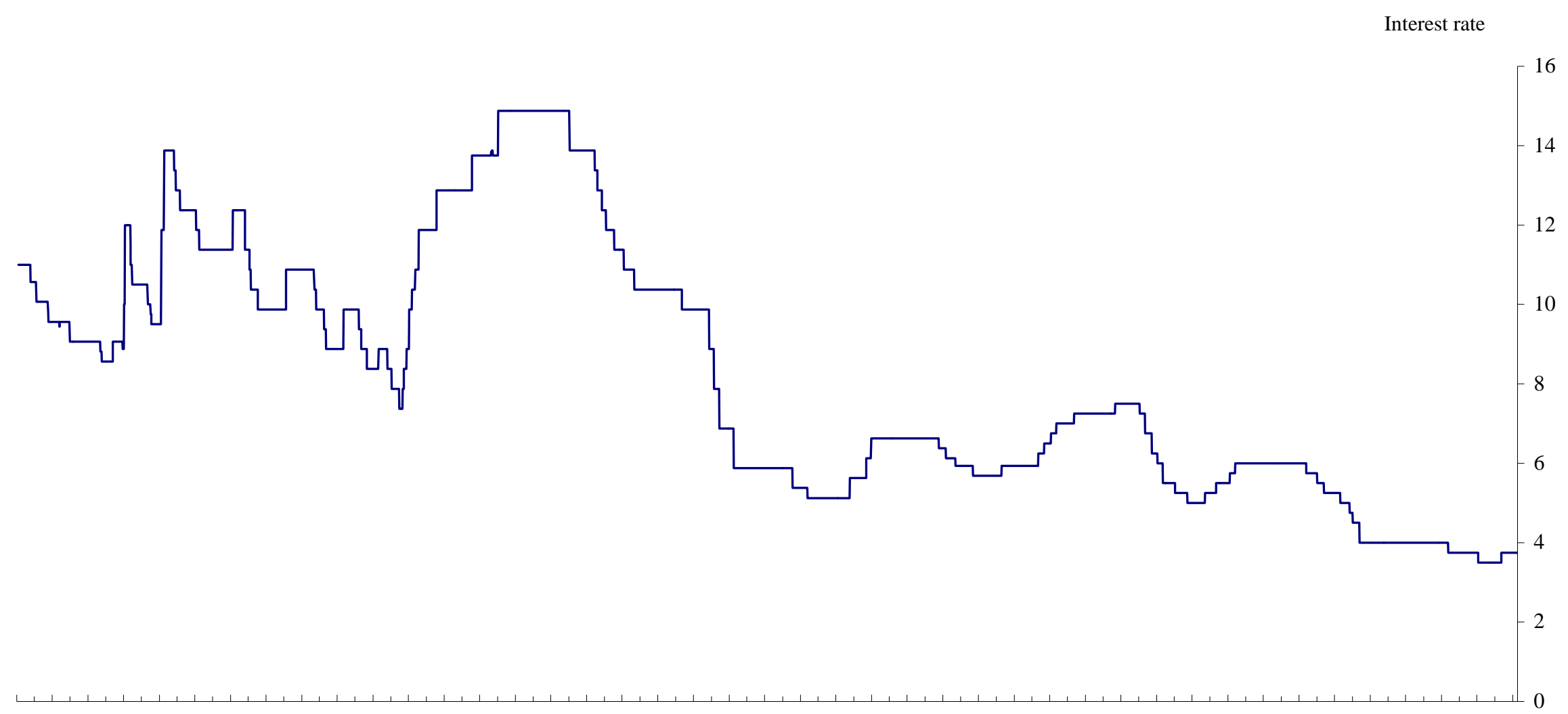

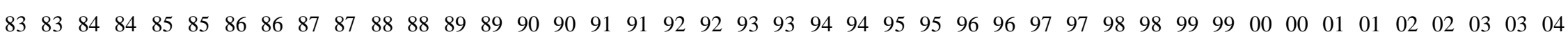


Figure 3

Inflation forecast

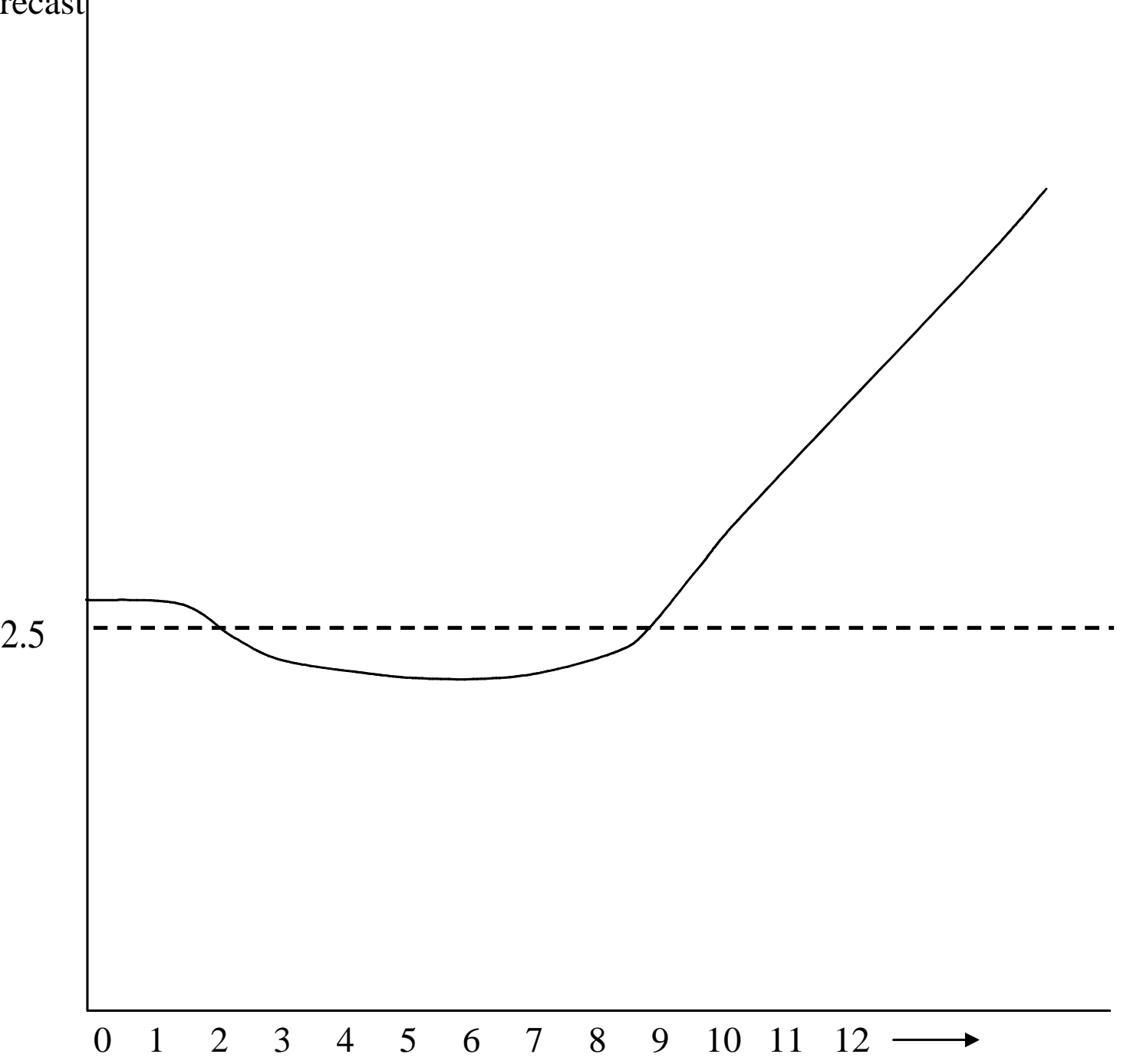


Table 1

Bank Forecast of GDP

\begin{tabular}{|c|c|c|c|c|c|c|c|c|c|c|c|}
\hline \multicolumn{12}{|c|}{ Forecast $t=$} \\
\hline & $\begin{array}{l}\text { Output } \\
\% \text { growth } \\
2003 \\
\text { estimate }\end{array}$ & $\begin{array}{l}\text { Output } \\
\% \text { growth } \\
\text { contemp- } \\
\text { oraneous }\end{array}$ & 0 & 1 & 2 & 3 & 4 & 5 & 6 & 7 & 8 \\
\hline 1997 Q3 & 3.19 & 3.89 & 3.39 & & & & & & & & \\
\hline Q4 & 3.36 & 3.93 & 4.02 & 2.82 & & & & & & & \\
\hline 1998 Q1 & 3.38 & 2.88 & 3.04 & 3.54 & 2.37 & & & & & & \\
\hline Q2 & 2.79 & 2.47 & 2.41 & 2.33 & 2.84 & 1.85 & & & & & \\
\hline Q3 & 3.51 & 2.40 & 1.99 & 1.86 & 1.76 & 2.11 & 1.80 & & & & \\
\hline Q4 & 2.82 & 2.02 & 1.95 & 1.66 & 1.71 & 1.64 & 1.33 & 1.83 & & & \\
\hline 1999 Q1 & 2.72 & 1.70 & 1.16 & 1.28 & 1.41 & 1.76 & 1.59 & 1.41 & 2.03 & & \\
\hline Q2 & 2.61 & 1.64 & 0.79 & 0.77 & 1.00 & 1.19 & 1.83 & 1.79 & 1.64 & 2.38 & \\
\hline Q3 & 2.60 & 2.30 & 1.32 & 0.99 & 0.68 & 0.84 & 1.29 & 2.11 & 2.15 & 1.93 & 2.63 \\
\hline Q4 & 3.26 & 2.75 & 2.50 & 1.90 & 1.20 & 0.83 & 1.01 & 1.54 & 2.27 & 2.41 & 2.33 \\
\hline 2000 Q1 & 3.96 & 3.11 & 2.92 & 2.82 & 2.41 & 1.49 & 1.36 & 1.33 & 1.69 & 2.39 & 2.61 \\
\hline Q2 & 4.30 & 3.36 & 2.94 & 2.70 & 2.80 & 2.58 & 1.72 & 1.82 & 1.65 & 2.09 & 2.56 \\
\hline Q3 & 3.94 & 2.98 & 2.56 & 2.58 & 2.47 & 2.51 & 2.73 & 1.99 & 2.24 & 2.02 & 2.44 \\
\hline Q4 & 2.93 & 2.72 & 2.73 & 2.48 & 2.45 & 2.24 & 2.42 & 2.80 & 2.58 & 2.61 & 2.48 \\
\hline 2001 Q1 & 2.56 & 3.01 & 2.86 & 2.76 & 2.50 & 2.57 & 2.27 & 2.61 & 2.92 & 2.97 & 2.83 \\
\hline Q2 & 2.23 & 2.65 & 2.25 & 2.30 & 2.39 & 2.51 & 2.61 & 2.35 & 2.70 & 3.01 & 3.11 \\
\hline Q3 & 1.80 & 2.24 & 1.62 & 2.03 & 2.07 & 2.31 & 2.53 & 2.65 & 2.38 & 2.82 & 3.02 \\
\hline Q4 & 1.95 & 1.71 & 2.09 & 1.82 & 2.46 & 2.22 & 2.40 & 2.63 & 2.70 & 2.39 & 2.83 \\
\hline 2002 Q1 & 1.44 & 1.37 & 1.37 & 1.92 & 1.98 & 2.68 & 2.10 & 2.48 & 2.81 & 2.74 & 2.39 \\
\hline Q2 & 1.55 & 1.75 & 1.35 & 1.48 & 1.97 & 2.26 & 2.72 & 2.37 & 2.51 & 2.79 & 2.70 \\
\hline Q3 & 1.93 & 2.26 & 1.82 & 1.62 & 1.78 & 2.05 & 2.42 & 2.71 & 2.62 & 2.50 & 2.76 \\
\hline Q4 & 1.99 & 2.31 & 2.29 & 2.34 & 2.32 & 2.43 & 2.27 & 2.33 & 2.48 & 2.81 & 2.48 \\
\hline 2003 Q1 & 1.84 & 2.10 & 2.53 & 3.06 & 2.91 & 2.95 & 2.76 & 2.49 & 2.24 & 2.42 & 2.89 \\
\hline Q2 & 1.98 & 1.84 & 2.38 & 2.58 & 3.18 & 2.75 & 2.95 & 2.79 & 2.66 & 2.15 & 2.42 \\
\hline Q3 & 1.89 & 1.89 & 1.59 & 2.00 & 2.33 & 3.17 & 2.94 & 3.15 & 2.69 & 2.70 & 2.11 \\
\hline
\end{tabular}


Table 2

Bank Forecast of RPIX

\begin{tabular}{|c|c|c|c|c|c|c|c|c|c|c|}
\hline & & \multicolumn{9}{|c|}{ Forecast $\mathrm{t}=$} \\
\hline & $\begin{array}{l}\text { RPIX \% change } \\
\text { over } 12 \text { months }\end{array}$ & 0 & 1 & 2 & 3 & 4 & 5 & 6 & 7 & 8 \\
\hline 1993 Q1 & 3.50 & 3.50 & & & & & & & & \\
\hline Q2 & 2.80 & 3.40 & 3.40 & & & & & & & \\
\hline Q3 & 3.30 & 2.90 & 3.40 & 3.00 & & & & & & \\
\hline Q4 & 2.70 & 3.30 & 3.00 & 3.20 & 3.10 & & & & & \\
\hline 1994 Q1 & 2.40 & 2.80 & 3.60 & 3.20 & 3.20 & 3.40 & & & & \\
\hline Q2 & 2.40 & 2.70 & 3.00 & 3.50 & 3.30 & 3.50 & 3.40 & & & \\
\hline Q3 & 2.00 & 2.30 & 2.90 & 3.10 & 3.50 & 3.30 & 3.60 & 3.40 & & \\
\hline Q4 & 2.50 & 2.10 & 2.60 & 3.00 & 3.20 & 3.40 & 3.30 & 3.70 & 3.30 & \\
\hline 1995 Q1 & 2.80 & 2.90 & 1.90 & 2.70 & 3.10 & 3.40 & 3.40 & 3.50 & & \\
\hline Q2 & 2.80 & 2.70 & 2.80 & 2.00 & 3.00 & 3.40 & 3.30 & 3.40 & 3.60 & \\
\hline Q3 & 3.10 & 2.90 & 3.00 & 3.10 & 2.30 & 3.20 & 3.40 & 3.20 & & \\
\hline Q4 & 3.00 & 3.20 & 3.00 & 3.10 & 3.20 & 2.40 & 3.20 & 3.30 & 3.20 & \\
\hline 1996 Q1 & 2.90 & 2.80 & 3.30 & 3.20 & 3.40 & 2.70 & 2.80 & 3.40 & 3.30 & \\
\hline Q2 & 2.80 & 2.70 & 2.70 & 3.50 & 3.50 & 3.80 & 2.70 & 2.40 & 3.10 & \\
\hline Q3 & 2.90 & 2.70 & 2.50 & 2.40 & 3.20 & 3.40 & 3.70 & 2.60 & 2.40 & \\
\hline Q4 & 3.10 & 3.10 & 2.40 & 2.30 & 2.20 & 3.00 & 3.20 & 3.40 & 2.50 & \\
\hline 1997 Q1 & 2.70 & 2.70 & 2.90 & 2.30 & 2.30 & 2.30 & 2.70 & 2.90 & 3.00 & \\
\hline Q2 & 2.70 & 2.60 & 2.40 & 2.80 & 2.30 & 2.20 & 2.30 & 2.70 & 2.80 & \\
\hline Q3 & 2.70 & 2.65 & 2.40 & 2.20 & 2.70 & 2.40 & 2.40 & 2.30 & 2.70 & 2.80 \\
\hline Q4 & 2.70 & 2.60 & 2.32 & 2.20 & 2.20 & 2.40 & 2.50 & 2.40 & 2.40 & 2.70 \\
\hline 1998 Q1 & 2.60 & 2.60 & 2.51 & 2.19 & 2.20 & 2.30 & 2.40 & 2.60 & 2.40 & 2.40 \\
\hline Q2 & 2.80 & 2.83 & 2.63 & 2.42 & 2.06 & 2.20 & 2.50 & 2.50 & 2.70 & 2.50 \\
\hline Q3 & 2.50 & 2.51 & 2.35 & 2.42 & 2.27 & 1.99 & 2.30 & 2.70 & 2.60 & 2.80 \\
\hline Q4 & 2.60 & 2.54 & 2.56 & 2.35 & 2.41 & 2.19 & 2.08 & 2.50 & 2.80 & 2.70 \\
\hline 1999 Q1 & 2.70 & 2.49 & 2.56 & 2.69 & 2.41 & 2.44 & 2.18 & 2.24 & 2.70 & 2.90 \\
\hline Q2 & 2.20 & 2.48 & 2.53 & 2.71 & 2.82 & 2.37 & 2.39 & 2.25 & 2.36 & 2.90 \\
\hline Q3 & 2.10 & 2.31 & 2.40 & 2.55 & 2.74 & 2.86 & 2.30 & 2.47 & 2.37 & 2.50 \\
\hline Q4 & 2.20 & 2.20 & 2.28 & 2.36 & 2.61 & 2.59 & 2.77 & 2.26 & 2.55 & 2.42 \\
\hline
\end{tabular}




\begin{tabular}{|r|l|l|l|l|l|l|l|l|l|l|}
2000 Q1 & 2.00 & 1.93 & 2.12 & 2.09 & 2.20 & 2.52 & 2.56 & 2.69 & 2.27 & 2.64 \\
\hline Q2 & 2.20 & 1.88 & 1.98 & 2.06 & 1.99 & 2.23 & 2.49 & 2.51 & 2.56 & 2.35 \\
\hline Q3 & 2.20 & 2.38 & 1.93 & 1.95 & 2.02 & 1.88 & 2.25 & 2.47 & 2.48 & 2.47 \\
\hline Q4 & 2.00 & 2.36 & 2.28 & 2.10 & 2.05 & 1.84 & 1.92 & 2.23 & 2.47 & 2.45 \\
\hline 2001 Q1 & 1.90 & 1.94 & 2.33 & 2.26 & 2.20 & 2.32 & 1.72 & 2.08 & 2.35 & 2.56 \\
\hline Q2 & 2.40 & 1.90 & 1.92 & 2.22 & 2.39 & 2.47 & 2.48 & 1.80 & 2.28 & 2.43 \\
\hline Q3 & 2.30 & 2.31 & 1.90 & 1.87 & 2.19 & 2.48 & 2.53 & 2.53 & 2.19 & 2.59 \\
\hline Q4 & 1.90 & 2.00 & 2.17 & 1.91 & 1.87 & 2.19 & 2.62 & 2.53 & 2.56 & 2.53 \\
\hline 2002 Q1 & 2.30 & 2.14 & 2.03 & 2.17 & 1.91 & 2.09 & 2.18 & 2.68 & 2.53 & 2.58 \\
\hline Q2 & 1.50 & 2.02 & 1.87 & 1.85 & 1.91 & 1.94 & 2.18 & 2.37 & 2.70 & 2.56 \\
\hline Q3 & 2.10 & 1.84 & 2.08 & 1.96 & 2.06 & 1.96 & 2.03 & 2.27 & 2.46 & 2.72 \\
\hline Q4 & 2.70 & 2.64 & 2.25 & 2.24 & 2.11 & 2.06 & 2.13 & 2.16 & 2.42 & 2.56 \\
\hline 2003 Q1 & 3.00 & 2.77 & 2.73 & 2.25 & 2.18 & 2.13 & 2.08 & 2.32 & 2.39 & 2.55 \\
\hline Q2 & 2.80 & 3.09 & 2.90 & 2.72 & 2.25 & 2.05 & 2.13 & 2.15 & 2.41 & 2.53 \\
\hline Q3 & 2.80 & 2.85 & 2.90 & 2.98 & 2.72 & 2.31 & 2.09 & 2.18 & 2.23 & 2.45 \\
\hline
\end{tabular}




\section{Table 3}

\section{Assumed Effects of Interest Rate Changes on}

GDP

\begin{tabular}{|c|c|c|c|c|c|c|c|c|c|}
\hline \multicolumn{10}{|c|}{ Quarters after Change } \\
\hline 0 & 1 & 2 & 3 & 4 & 5 & 6 & 7 & 8 & \\
\hline 0 & 0.12 & 0.21 & 0.3 & $\begin{array}{l}0.35 \\
(0.32) *\end{array}$ & $\begin{array}{l}0.35 \\
(0.30)\end{array}$ & $\begin{array}{l}0.29 \\
(0.24)\end{array}$ & $\begin{array}{l}0.25 \\
(0.12)\end{array}$ & $\begin{array}{l}0.1 \\
(0.03)\end{array}$ & $1 \% \mathrm{chang} \mathrm{e}^{+}$ \\
\hline 0 & 0 & 0.1 & 0.1 & $\begin{array}{l}0.09 \\
(0.08) *\end{array}$ & $\begin{array}{l}0.09 \\
(0.07)\end{array}$ & $\begin{array}{l}0.07 \\
(0.05)\end{array}$ & $\begin{array}{l}0.06 \\
(0.03)\end{array}$ & $\begin{array}{l}0.04 \\
(0.01)\end{array}$ & $1 / 4 \% \mathrm{change}^{+}$ \\
\hline
\end{tabular}

RPI

Quarters after Change

\begin{tabular}{|c|c|c|c|c|c|c|c|c|c|}
\hline 0 & 1 & 2 & 3 & 4 & 5 & 6 & 7 & 8 & \\
\hline 0 & 0 & 0 & 0.04 & 0.11 & 0.18 & 0.25 & 0.32 & 0.3 & $1 \%$ change \\
\hline 0 & 0 & 0 & 0.01 & 0.03 & 0.05 & 0.06 & 0.08 & 0.07 & $1 / 4 \%$ change \\
\hline
\end{tabular}

Interest Rate Changes in Months applied to Quarters
\begin{tabular}{|c|c|}
\hline Dec - Feb & Q1 \\
\hline Mar-May & Q2 \\
\hline June - Aug & Q3 \\
\hline Sept B Nov & Q4 \\
\hline
\end{tabular}

* The figures in brackets indicate my estimate, (from MPC 1999), of the effect on output of a $1 \%$ reduction in output maintained for one year only.

+ The effect of an increase in interest rates being a reduction in output and, subsequently, in inflation, (and vice versa). The effects are assumed to be symmetrical for interest rate cuts. 
Table 4: Effect on GDP

\begin{tabular}{|c|c|c|c|c|c|c|c|c|c|c|}
\hline \multicolumn{11}{|c|}{ Effect on GDP } \\
\hline Date & \begin{tabular}{|l|} 
Interest \\
Change
\end{tabular} & 0 & 1 & 2 & 3 & 4 & 5 & 6 & 7 & 8 \\
\hline 1997 Q3 & 0.75 & 0.03 & 0.03 & & 0.07 & -0.09 & & -0.07 & -0.06 & \\
\hline Q4 & 0.25 & 0.01 & 0.09 & 0.05 & & 0.09 & -0.09 & & -0.06 & -0.04 \\
\hline 1998 Q1 & & & 0.03 & 0.15 & 0.07 & & 0.09 & -0.07 & & -0.04 \\
\hline Q2 & & & & 0.05 & 0.21 & 0.09 & & 0.07 & -0.06 & \\
\hline Q3 & 0.25 & 0.01 & & & 0.07 & 0.26 & 0.09 & & 0.06 & -0.04 \\
\hline Q4 & -0.75 & -0.03 & 0.03 & & & 0.09 & 0.25 & 0.07 & & 0.04 \\
\hline 1999 Q1 & -1.25 & -0.04 & -0.09 & 0.05 & & & 0.09 & 0.21 & 0.06 & \\
\hline Q2 & -0.25 & -0.01 & -0.15 & -0.15 & 0.07 & & & 0.07 & 0.18 & 0.04 \\
\hline Q3 & -0.25 & -0.01 & -0.03 & -0.26 & -0.21 & 0.09 & & & 0.06 & 0.12 \\
\hline Q4 & 0.5 & 0.02 & -0.03 & -0.05 & -0.37 & -0.26 & 0.09 & & & 0.04 \\
\hline 2000 Q1 & 0.5 & 0.02 & 0.06 & -0.05 & -0.07 & -0.44 & -0.25 & 0.07 & & \\
\hline Q2 & & & 0.06 & 0.1 & -0.07 & -0.09 & -0.44 & -0.21 & 0.06 & \\
\hline Q3 & & & & 0.1 & 0.14 & -0.09 & -0.09 & -0.36 & -0.18 & 0.04 \\
\hline Q4 & & & & & 0.14 & 0.18 & -0.09 & -0.07 & -0.31 & -0.12 \\
\hline 2001 Q1 & -0.25 & -0.01 & & & & 0.18 & 0.18 & -0.07 & -0.06 & -0.2 \\
\hline Q2 & -0.5 & -0.02 & -0.03 & & & & 0.18 & 0.14 & -0.06 & -0.04 \\
\hline Q3 & -0.25 & -0.01 & -0.06 & -0.05 & & & & 0.14 & 0.12 & -0.04 \\
\hline Q4 & -1 & -0.03 & -0.03 & -0.1 & -0.07 & & & & 0.12 & 0.08 \\
\hline 2002 Q1 & & & -0.12 & -0.05 & -0.14 & -0.09 & & & & 0.08 \\
\hline Q2 & & & & -0.21 & -0.07 & -0.18 & -0.09 & & & \\
\hline Q3 & & & & & -0.3 & -0.09 & -0.18 & -0.07 & & \\
\hline Q4 & & & & & & -0.35 & -0.09 & -0.19 & -0.06 & \\
\hline 2003 Q1 & -0.25 & -0.01 & & & & & -0.35 & -0.07 & -0.12 & -0.04 \\
\hline Q2 & & & -0.03 & & & & & -0.29 & -0.06 & -0.08 \\
\hline Q3 & -0.25 & -0.01 & & -0.05 & & & & & -0.25 & -0.04 \\
\hline
\end{tabular}


Table 5: Effect on RPIX

\begin{tabular}{|c|c|c|c|c|c|c|c|c|c|c|}
\hline \multicolumn{11}{|l|}{ Effect } \\
\hline Date & $\begin{array}{l}\text { Interest } \\
\text { Change }\end{array}$ & 0 & 1 & 2 & 3 & 4 & 5 & 6 & 7 & 8 \\
\hline 1993 Q1 & -1.00 & & & & & & & & & \\
\hline \multicolumn{11}{|l|}{ Q2 } \\
\hline \multicolumn{11}{|l|}{ Q3 } \\
\hline Q4 & -0.50 & & & & & & & & & \\
\hline 1994 Q1 & -0.25 & & & & & & & & & \\
\hline \multicolumn{11}{|l|}{ Q2 } \\
\hline Q3 & & & & & -0.02 & & & -0.25 & & \\
\hline Q4 & 0.50 & & & & -0.01 & -0.06 & & & -0.30 & \\
\hline 1995 Q1 & 0.50 & & & & & -0.03 & -0.10 & & & -0.30 \\
\hline Q2 & & & & & & & -0.05 & -0.12 & & \\
\hline Q3 & & & & & 0.02 & & & -0.06 & -0.15 & \\
\hline Q4 & -0.25 & & & & 0.02 & 0.06 & & & -0.08 & -0.15 \\
\hline 1996 Q1 & -0.25 & & & & & 0.06 & 0.10 & & & -0.08 \\
\hline Q2 & & & & & & & 0.10 & 0.12 & & \\
\hline Q3 & -0.25 & & & & -0.01 & & & 0.12 & 0.15 & \\
\hline Q4 & 0.25 & & & & -0.01 & -0.03 & & & 0.15 & 0.15 \\
\hline 1997 Q1 & & & & & & -0.03 & -0.05 & & & 0.15 \\
\hline Q2 & 0.25 & & & & -0.01 & & -0.05 & -0.06 & & \\
\hline Q3 & 0.75 & & & & 0.01 & -0.03 & & -0.06 & -0.08 & \\
\hline Q4 & 0.25 & & & & & 0.03 & -0.05 & & -0.08 & -0.08 \\
\hline 1998 Q1 & & & & & 0.01 & & 0.05 & -0.06 & & -0.08 \\
\hline Q2 & & & & & 0.03 & 0.03 & & 0.06 & -0.08 & \\
\hline Q3 & 0.25 & & & & 0.01 & 0.08 & 0.05 & & 0.08 & -0.08 \\
\hline Q4 & -0.75 & & & & & 0.03 & 0.14 & 0.06 & & 0.08 \\
\hline 1999 Q1 & -1.25 & & & & & & 0.05 & 0.18 & 0.08 & \\
\hline Q2 & -0.25 & & & & 0.01 & & & 0.06 & 0.24 & 0.08 \\
\hline Q3 & -0.25 & & & & -0.03 & 0.03 & & & 0.08 & 0.24 \\
\hline Q4 & 0.50 & & & & -0.05 & -0.08 & 0.05 & & & 0.08 \\
\hline $\mid 2000$ Q1 & 0.50 & & & & -0.01 & -0.14 & -0.14 & 0.06 & & \\
\hline
\end{tabular}




\begin{tabular}{|r|l|l|l|l|l|l|l|l|l|l|}
\hline Q2 & & & & -0.01 & -0.03 & -0.23 & -0.18 & 0.08 & \\
\hline$Q 3$ & & & & & 0.02 & -0.03 & -0.05 & -0.31 & -0.24 & 0.08 \\
\hline $\mathbf{Q}$ & & & & & 0.02 & 0.06 & -0.05 & -0.06 & -0.38 & -0.24 \\
\hline 2001 Q1 & -0.25 & & & & & 0.06 & 0.09 & -0.06 & -0.08 & -0.38 \\
\hline$Q 2$ & -0.50 & & & & & & 0.09 & 0.12 & -0.08 & -0.08 \\
\hline$Q 3$ & -0.25 & & & & & & & 0.12 & 0.16 & -0.08 \\
\hline$Q 4$ & -1.00 & & & & -0.01 & & & & 0.16 & 0.16 \\
\hline 2002 Q1 & & & & -0.02 & -0.03 & & & & 0.16 \\
\hline$Q 2$ & & & & & -0.01 & -0.06 & -0.05 & & & \\
\hline$Q 3$ & & & & & -0.04 & -0.03 & -0.09 & -0.06 & & \\
\hline $\mathbf{Q}$ & & & & & & -0.11 & -0.05 & -0.12 & -0.08 & \\
\hline 2003 Q1 & -0.25 & & & & & & -0.18 & -0.06 & -0.16 & -0.08 \\
\hline$Q 2$ & & & & & & & -0.25 & -0.08 & -0.16 \\
\hline$Q 3$ & -0.25 & & & & & & & & -0.32 & -0.08 \\
\hline
\end{tabular}


Table 6: Adjusted GDP Forecast

\begin{tabular}{|c|c|c|c|c|c|c|c|c|c|c|c|}
\hline & & & & & & & Adjusted & & & & \\
\hline Date & IR & Actual & 0 & 1 & 2 & 3 & 4 & 5 & 6 & 7 & 8 \\
\hline 1997 Q3 & 7 & 3.89 & 3.42 & & & & & & & & \\
\hline Q4 & 7.25 & 3.93 & 4.03 & 2.91 & & & & & & & \\
\hline 1998 Q1 & 7.25 & 2.88 & 3.04 & 3.57 & 2.52 & & & & & & \\
\hline Q2 & 7.25 & 2.47 & 2.41 & 2.33 & 2.89 & 2.06 & & & & & \\
\hline Q3 & 7.50 & 2.4 & 2 & 1.86 & 1.76 & 2.18 & 2.06 & & & & \\
\hline Q4 & 6.75 & 2.02 & 1.92 & 1.69 & 1.71 & 1.64 & 1.42 & 2.08 & & & \\
\hline 1999 Q1 & 5.50 & 1.7 & 1.12 & 1.19 & 1.46 & 1.76 & 1.59 & 1.5 & 2.24 & & \\
\hline Q2 & 5.25 & 1.64 & 0.78 & 0.62 & 0.85 & 1.26 & 1.83 & 1.79 & 1.71 & 2.56 & \\
\hline Q3 & 5.00 & 2.3 & 1.31 & 0.96 & 0.42 & 0.63 & 1.38 & 2.11 & 2.15 & 1.99 & 2.75 \\
\hline Q4 & 5.50 & 2.75 & 2.52 & 1.87 & 1.15 & 0.46 & 0.75 & 1.63 & 2.27 & 2.41 & 2.37 \\
\hline 2000 Q1 & 6.00 & 3.11 & 2.94 & 2.88 & 2.36 & 1.42 & 0.92 & 1.08 & 1.76 & 2.39 & 2.61 \\
\hline Q2 & 6.00 & 3.36 & 2.94 & 2.76 & 2.9 & 2.51 & 1.63 & 1.38 & 1.44 & 2.15 & 2.56 \\
\hline Q3 & 6.00 & 2.98 & 2.56 & 2.58 & 2.57 & 2.65 & 2.64 & 1.9 & 1.88 & 1.84 & 2.48 \\
\hline Q4 & 6.00 & 2.72 & 2.73 & 2.48 & 2.45 & 2.38 & 2.6 & 2.71 & 2.51 & 2.3 & 2.36 \\
\hline 2001 Q1 & 5.75 & 3.01 & 2.85 & 2.76 & 2.5 & 2.57 & 2.45 & 2.79 & 2.85 & 2.91 & 2.63 \\
\hline Q2 & 5.25 & 2.65 & 2.23 & 2.27 & 2.39 & 2.51 & 2.61 & 2.53 & 2.84 & 2.95 & 3.07 \\
\hline Q3 & 5.00 & 2.24 & 1.61 & 1.97 & 2.02 & 2.31 & 2.53 & 2.65 & 2.52 & 2.94 & 2.98 \\
\hline Q4 & 4.00 & 1.71 & 2.06 & 1.79 & 2.36 & 2.15 & 2.4 & 2.63 & 2.7 & 2.51 & 2.91 \\
\hline 2002 Q1 & 4.00 & 1.37 & 1.37 & 1.8 & 1.93 & 2.54 & 2.01 & 2.48 & 2.81 & 2.74 & 2.47 \\
\hline Q2 & 4.00 & 1.75 & 1.35 & 1.48 & 1.76 & 2.19 & 2.54 & 2.28 & 2.51 & 2.79 & 2.7 \\
\hline Q3 & 4.00 & 2.26 & 1.82 & 1.62 & 1.78 & 1.75 & 2.33 & 2.53 & 2.55 & 2.5 & 2.76 \\
\hline Q4 & 4.00 & 2.31 & 2.29 & 2.34 & 2.32 & 2.43 & 1.92 & 2.24 & 2.29 & 2.75 & 2.48 \\
\hline 2003 Q1 & 3.75 & 2.1 & 2.52 & 3.06 & 2.91 & 2.95 & 2.76 & 2.14 & 2.17 & 2.3 & 2.85 \\
\hline Q2 & 3.75 & 1.84 & 2.38 & 2.55 & 3.18 & 2.75 & 2.95 & 2.79 & 2.37 & 2.09 & 2.34 \\
\hline Q3 & 3.50 & 1.89 & 1.58 & 2 & 2.28 & 3.17 & 2.94 & 3.15 & 2.69 & 2.45 & 2.07 \\
\hline
\end{tabular}


Table 7: Adjusted RPIX Forecast

\begin{tabular}{|c|c|c|c|c|c|c|c|c|c|c|c|}
\hline & & & & Adjusted & RPIX & Forceasts & & & & & \\
\hline & IR & Actual & 0 & 1 & 2 & 3 & 4 & 5 & 6 & 7 & 8 \\
\hline 1997 Q3 & 7 & 2.70 & 2.65 & 2.40 & 2.20 & 2.71 & 2.37 & 2.40 & 2.24 & 2.62 & 2.80 \\
\hline Q4 & 7.25 & 2.70 & 2.60 & 2.32 & 2.20 & 2.20 & 2.43 & 2.45 & 2.40 & 2.32 & 2.62 \\
\hline 1998 Q1 & 7.25 & 2.60 & 2.60 & 2.51 & 2.19 & 2.21 & 2.30 & 2.45 & 2.54 & 2.40 & 2.32 \\
\hline Q2 & 7.25 & 2.80 & 2.83 & 2.63 & 2.42 & 2.09 & 2.23 & 2.50 & 2.56 & 2.62 & 2.50 \\
\hline Q3 & 7.50 & 2.50 & 2.51 & 2.35 & 2.42 & 2.28 & 2.07 & 2.35 & 2.70 & 2.68 & 2.72 \\
\hline Q4 & 6.75 & 2.60 & 2.54 & 2.56 & 2.35 & 2.41 & 2.22 & 2.22 & 2.56 & 2.80 & 2.78 \\
\hline 1999 Q1 & 5.50 & 2.70 & 2.49 & 2.56 & 2.69 & 2.41 & 2.44 & 2.23 & 2.42 & 2.78 & 2.90 \\
\hline Q2 & 5.25 & 2.20 & 2.48 & 2.53 & 2.71 & 2.83 & 2.37 & 2.39 & 2.31 & 2.60 & 2.98 \\
\hline Q3 & 5.00 & 2.10 & 2.31 & 2.40 & 2.55 & 2.71 & 2.89 & 2.30 & 2.47 & 2.45 & 2.74 \\
\hline Q4 & 5.50 & 2.20 & 2.20 & 2.28 & 2.36 & 2.56 & 2.51 & 2.82 & 2.26 & 2.55 & 2.50 \\
\hline 2000 Q1 & 6.00 & 2.00 & 1.93 & 2.12 & 2.09 & 2.19 & 2.38 & 2.42 & 2.75 & 2.27 & 2.64 \\
\hline Q2 & 6.00 & 2.20 & 1.88 & 1.98 & 2.06 & 1.98 & 2.20 & 2.26 & 2.33 & 2.64 & 2.35 \\
\hline Q3 & 6.00 & 2.20 & 2.38 & 1.93 & 1.95 & 2.04 & 1.85 & 2.20 & 2.16 & 2.24 & 2.55 \\
\hline Q4 & 6.00 & 2.00 & 2.36 & 2.28 & 2.10 & 2.07 & 1.90 & 1.87 & 2.17 & 2.09 & 2.21 \\
\hline 2001 Q1 & 5.75 & 1.90 & 1.94 & 2.33 & 2.26 & 2.20 & 2.38 & 1.81 & 2.02 & 2.27 & 2.18 \\
\hline Q2 & 5.25 & 2.40 & 1.90 & 1.92 & 2.22 & 2.39 & 2.47 & 2.57 & 1.92 & 2.20 & 2.35 \\
\hline Q3 & 5.00 & 2.30 & 2.31 & 1.90 & 1.87 & 2.19 & 2.48 & 2.53 & 2.65 & 2.35 & 2.51 \\
\hline Q4 & 4.00 & 1.90 & 2.00 & 2.17 & 1.91 & 1.86 & 2.19 & 2.62 & 2.53 & 2.72 & 2.69 \\
\hline 2002 Q1 & 4.00 & 2.30 & 2.14 & 2.03 & 2.17 & 1.89 & 2.06 & 2.18 & 2.68 & 2.53 & 2.74 \\
\hline Q2 & 4.00 & 1.50 & 2.02 & 1.87 & 1.85 & 1.90 & 1.88 & 2.13 & 2.37 & 2.70 & 2.56 \\
\hline Q3 & 4.00 & 2.10 & 1.84 & 2.08 & 1.96 & 2.02 & 1.93 & 1.94 & 2.21 & 2.46 & 2.72 \\
\hline Q4 & 4.00 & 2.70 & 2.64 & 2.25 & 2.24 & 2.11 & 1.95 & 2.08 & 2.04 & 2.34 & 2.56 \\
\hline 2003 Q1 & 3.75 & 3.00 & 2.77 & 2.73 & 2.25 & 2.18 & 2.13 & 1.90 & 2.26 & 2.23 & 2.47 \\
\hline Q2 & 3.75 & 2.80 & 3.09 & 2.90 & 2.72 & 2.25 & 2.05 & 2.13 & 1.90 & 2.33 & 2.37 \\
\hline Q3 & 3.50 & 2.80 & 2.85 & 2.90 & 2.98 & 2.72 & 2.31 & 2.09 & 2.18 & 1.91 & 2.37 \\
\hline
\end{tabular}


Table 8: Adjusted GDP Forecast (rotated)

\begin{tabular}{|c|c|c|c|c|c|c|c|c|c|c|c|}
\hline $\begin{array}{c}\text { Date } \\
1997 \text { Q3 }\end{array}$ & $\begin{array}{c}\text { IR } \\
7 \\
\end{array}$ & $\begin{array}{c}\text { Actual } \\
3.89 \\
\end{array}$ & $\begin{array}{l}0 \\
4.64\end{array}$ & $\begin{array}{l}1 \\
4.03 \\
\end{array}$ & $\begin{array}{l}2 \\
3.57\end{array}$ & $\begin{array}{l}3 \\
2.89\end{array}$ & $\begin{array}{l}4 \\
2.18 \\
\end{array}$ & $\begin{array}{l}5 \\
1.42 \\
\end{array}$ & $\begin{array}{l}6 \\
1.5 \\
\end{array}$ & $\begin{array}{l}7 \\
1.71 \\
\end{array}$ & $\begin{array}{l}8 \\
1.99 \\
\end{array}$ \\
\hline Q4 & 7.25 & 3.93 & 4.18 & 3.04 & 2.33 & 1.76 & 1.64 & 1.59 & 1.79 & 2.15 & 2.41 \\
\hline 1998 Q1 & 7.25 & 2.88 & 2.88 & 2.41 & 1.86 & 1.71 & 1.76 & 1.83 & 2.11 & 2.27 & 2.39 \\
\hline Q2 & 7.25 & 2.47 & 2.47 & 2 & 1.69 & 1.46 & 1.26 & 1.38 & 1.63 & 1.76 & 2.15 \\
\hline Q3 & 7.50 & 2.4 & 2.65 & 1.92 & 1.19 & 0.85 & 0.63 & 0.75 & 1.08 & 1.44 & 1.84 \\
\hline Q4 & 6.75 & 2.02 & 1.27 & 1.12 & 0.62 & 0.42 & 0.46 & 0.92 & 1.38 & 1.88 & 2.3 \\
\hline 1999 Q1 & 5.50 & 1.7 & 0.45 & 0.78 & 0.96 & 1.15 & 1.42 & 1.63 & 1.9 & 2.51 & 2.91 \\
\hline Q2 & 5.25 & 1.64 & 1.39 & 1.31 & 1.87 & 2.36 & 2.51 & 2.64 & 2.71 & 2.85 & 2.95 \\
\hline Q3 & 5.00 & 2.3 & 2.05 & 2.52 & 2.88 & 2.9 & 2.65 & 2.6 & 2.79 & 2.84 & 2.94 \\
\hline Q4 & 5.50 & 2.75 & 3.25 & 2.94 & 2.76 & 2.57 & 2.38 & 2.45 & 2.53 & 2.52 & 2.51 \\
\hline 2000 Q1 & 6.00 & 3.11 & 3.61 & 2.94 & 2.58 & 2.45 & 2.57 & 2.61 & 2.65 & 2.7 & 2.74 \\
\hline Q2 & 6.00 & 3.36 & 3.36 & 2.56 & 2.48 & 2.5 & 2.51 & 2.53 & 2.63 & 2.81 & 2.79 \\
\hline Q3 & 6.00 & 2.98 & 2.98 & 2.73 & 2.76 & 2.39 & 2.31 & 2.4 & 2.48 & 2.51 & 2.5 \\
\hline Q4 & 6.00 & 2.72 & 2.72 & 2.85 & 2.27 & 2.02 & 2.15 & 2.01 & 2.28 & 2.55 & 2.75 \\
\hline 2001 Q1 & 5.75 & 3.01 & 2.76 & 2.23 & 1.97 & 2.36 & 2.54 & 2.54 & 2.53 & 2.29 & 2.3 \\
\hline Q2 & 5.25 & 2.65 & 2.15 & 1.61 & 1.79 & 1.93 & 2.19 & 2.33 & 2.24 & 2.17 & 2.09 \\
\hline Q3 & 5.00 & 2.24 & 1.99 & 2.06 & 1.8 & 1.76 & 1.75 & 1.92 & 2.14 & 2.37 & 2.45 \\
\hline Q4 & 4.00 & 1.71 & 0.71 & 1.37 & 1.48 & 1.78 & 2.43 & 2.76 & 2.79 & 2.69 & \\
\hline 2002 Q1 & 4.00 & 1.37 & 1.37 & 1.35 & 1.62 & 2.32 & 2.95 & 2.95 & 3.15 & & \\
\hline Q2 & 4.00 & 1.75 & 1.75 & 1.82 & 2.34 & 2.91 & 2.75 & 2.94 & & & \\
\hline Q3 & 4.00 & 2.26 & 2.26 & 2.29 & 3.06 & 3.18 & 3.17 & & & & \\
\hline Q4 & 4.00 & 2.31 & 2.31 & 2.52 & 2.55 & 2.28 & & & & & \\
\hline 2003 Q1 & 3.75 & 2.1 & 1.85 & 2.38 & 2 & & & & & & \\
\hline Q2 & 3.75 & 1.84 & 1.84 & 1.58 & & & & & & & \\
\hline Q3 & 3.50 & 1.89 & 1.64 & & & & & & & & \\
\hline
\end{tabular}


Table 9: Adjusted RPIX Forecasts (rotated)

\begin{tabular}{|c|c|c|c|c|c|c|c|c|c|c|c|}
\hline $\begin{array}{c}\text { Date } \\
\mid 1997 \text { Q3 }\end{array}$ & $\begin{array}{l}\text { IR } \\
7\end{array}$ & $\begin{array}{c}\text { Actual } \\
2.7\end{array}$ & $\begin{array}{l}0 \\
2.65\end{array}$ & $\begin{array}{l}1 \\
2.32\end{array}$ & $\begin{array}{l}2 \\
2.19\end{array}$ & $\begin{array}{l}3 \\
2.09\end{array}$ & $\begin{array}{l}4 \\
2.07\end{array}$ & $\begin{array}{l}5 \\
2.22\end{array}$ & $\begin{array}{l}6 \\
2.42\end{array}$ & $\begin{array}{ll}7 & \\
2.6\end{array}$ & $\begin{array}{l}8 \\
2.74\end{array}$ \\
\hline Q4 & 7.25 & 2.7 & 2.6 & 2.51 & 2.42 & 2.28 & 2.22 & 2.23 & 2.31 & 2.45 & 2.5 \\
\hline 1998 Q1 & 7.25 & 2.6 & 2.6 & 2.63 & 2.42 & 2.41 & 2.44 & 2.39 & 2.47 & 2.55 & 2.64 \\
\hline Q2 & 7.25 & 2.8 & 2.83 & 2.35 & 2.35 & 2.41 & 2.37 & 2.3 & 2.26 & 2.27 & 2.35 \\
\hline Q3 & 7.50 & 2.5 & 2.51 & 2.56 & 2.69 & 2.83 & 2.89 & 2.82 & 2.75 & 2.64 & 2.55 \\
\hline Q4 & 6.75 & 2.6 & 2.54 & 2.56 & 2.71 & 2.71 & 2.51 & 2.42 & 2.33 & 2.24 & 2.21 \\
\hline 1999 Q1 & 5.50 & 2.7 & 2.49 & 2.53 & 2.55 & 2.56 & 2.38 & 2.26 & 2.16 & 2.09 & 2.18 \\
\hline Q2 & 5.25 & 2.2 & 2.48 & 2.4 & 2.36 & 2.19 & 2.2 & 2.2 & 2.17 & 2.27 & 2.35 \\
\hline Q3 & 5.00 & 2.1 & 2.31 & 2.28 & 2.09 & 1.98 & 1.85 & 1.87 & 2.02 & 2.2 & 2.51 \\
\hline Q4 & 5.50 & 2.2 & 2.2 & 2.12 & 2.06 & 2.04 & 1.9 & 1.81 & 1.92 & 2.35 & 2.69 \\
\hline 2000 Q1 & 6.00 & 2 & 1.93 & 1.98 & 1.95 & 2.07 & 2.38 & 2.57 & 2.65 & 2.72 & 2.74 \\
\hline Q2 & 6.00 & 2.2 & 1.88 & 1.93 & 2.1 & 2.2 & 2.47 & 2.53 & 2.53 & 2.53 & 2.56 \\
\hline Q3 & 6.00 & 2.2 & 2.38 & 2.28 & 2.26 & 2.39 & 2.48 & 2.62 & 2.68 & 2.7 & 2.72 \\
\hline Q4 & 6.00 & 2 & 2.36 & 2.33 & 2.22 & 2.19 & 2.19 & 2.18 & 2.37 & 2.46 & 2.56 \\
\hline 2001 Q1 & 5.75 & 1.9 & 1.94 & 1.92 & 1.87 & 1.86 & 2.06 & 2.13 & 2.21 & 2.34 & 2.47 \\
\hline Q2 & 5.25 & 2.4 & 1.9 & 1.9 & 1.91 & 1.89 & 1.88 & 1.94 & 2.04 & 2.23 & 2.37 \\
\hline Q3 & 5.00 & 2.3 & 2.31 & 2.17 & 2.17 & 1.9 & 1.93 & 2.08 & 2.26 & 2.33 & 2.37 \\
\hline Q4 & 4.00 & 1.9 & 2 & 2.03 & 1.85 & 2.02 & 1.95 & 1.9 & 1.9 & 1.91 & \\
\hline 2002 Q1 & 4.00 & 2.3 & 2.14 & 1.87 & 1.96 & 2.11 & 2.13 & 2.13 & 2.18 & & \\
\hline Q2 & 4.00 & 1.5 & 2.02 & 2.08 & 2.24 & 2.18 & 2.05 & 2.09 & & & \\
\hline Q3 & 4.00 & 2.1 & 1.84 & 2.25 & 2.25 & 2.25 & 2.31 & & & & \\
\hline Q4 & 4.00 & 2.7 & 2.64 & 2.73 & 2.72 & 2.72 & & & & & \\
\hline 2003 Q1 & 3.75 & 3 & 2.77 & 2.9 & 2.98 & & & & & & \\
\hline Q2 & 3.75 & 2.8 & 3.09 & 2.9 & & & & & & & \\
\hline Q3 & 3.50 & 2.8 & 2.85 & & & & & & & & \\
\hline
\end{tabular}


Table 10: Regression in levels (adj. Db)

$\operatorname{IR}(\mathrm{t})=\mathrm{a}+\mathrm{b}^{*}(\Pi(\mathrm{t}+\mathrm{i})-2.5)+\mathrm{c}^{*}(\operatorname{GDP}(\mathrm{t}+\mathrm{i})-2.25)+\mathrm{d}^{*} \operatorname{IR}(\mathrm{t}-1)$

\begin{tabular}{|c|c|c|c|c|c|}
\hline $\begin{array}{c}\text { a } \\
\text { (P value) } \\
\text { (St. Er.) }\end{array}$ & $\begin{array}{c}\text { b } \\
\text { (P value) } \\
\text { (St. Er.) }\end{array}$ & $\begin{array}{c}\text { c } \\
\text { (P value) } \\
\text { (St. } \text { Er.) }\end{array}$ & $\begin{array}{c}\text { d } \\
\text { (Pvalue) } \\
\text { (St. Er.) }\end{array}$ & R sq. & DW \\
\hline-0.12 & 2.29 & -0.18 & 1.01 & 0.92 & 2.39 \\
\hline 0.83 & 0.00 & 0.52 & 0.00 & & \\
\hline 0.59 & 0.43 & 0.27 & 0.09 & & \\
\hline 0.53 & 1.79 & 0.14 & 0.91 & 0.91 & 1.54 \\
\hline 0.51 & 0.00 & 0.62 & 0.00 & & \\
\hline 0.79 & 0.37 & 0.29 & 0.11 & & \\
\hline 0.03 & 0.98 & 0.47 & 0.99 & 0.87 & 1.45 \\
\hline 0.97 & 0.05 & 0.21 & 0.00 & & \\
\hline 1.09 & 0.45 & 0.35 & 0.16 & & \\
\hline-0.92 & 0.57 & 0.68 & 1.15 & 0.89 & 1.72 \\
\hline 0.38 & 0.18 & 0.02 & 0.00 & & \\
\hline 1.03 & 0.41 & 0.27 & 0.16 & & \\
\hline-0.98 & 0.57 & 0.67 & 1.18 & 0.91 & 1.80 \\
\hline 0.25 & 0.15 & 0.00 & 0.00 & & \\
\hline 0.83 & 0.38 & 0.21 & 0.13 & & \\
\hline-1.05 & 0.30 & 0.62 & 1.18 & 0.93 & 2.19 \\
\hline 0.06 & 0.32 & 0.00 & 0.00 & & \\
\hline 0.54 & 0.29 & 0.15 & 0.09 & & \\
\hline-0.57 & 0.07 & 0.48 & 1.09 & 0.93 & 2.20 \\
\hline 0.16 & 0.75 & 0.00 & 0.00 & & \\
\hline 0.40 & 0.24 & 0.12 & 0.07 & & \\
\hline
\end{tabular}




$\begin{array}{lllllll}1 & 0.01 & -0.08 & 0.38 & 0.97 & 0.93 & 1.96 \\ & 0.97 & 0.70 & 0.00 & 0.00 & & \\ & 0.34 & 0.23 & 0.10 & 0.05 & & \\ & & & & & & \\ & 0.40 & -0.00 & 0.30 & 0.90 & 0.92 & \\ & 0.29 & 0.97 & 0.01 & 0.00 & & \\ & 0.37 & 0.22 & 0.11 & 0.06 & & \\ & & & & & & \\ & & & & & \\ & 0.57 & -0.02 & 0.46 & 0.85 & 0.93 & \\ & 0.12 & 0.90 & 0.00 & 0.00 & & \\ & 0.36 & 0.19 & 0.12 & 0.06 & & \end{array}$


Table 11: Regression in first differences (adj. DB)

(i) $\quad \operatorname{DIR}(\mathrm{t})=\mathrm{b}^{*}(\Pi(\mathrm{t}+\mathrm{i})-2.5)+\mathrm{c} *(\mathrm{GDP}(\mathrm{t}+\mathrm{i})-2.25)+\mathrm{d}^{*} \mathrm{DIR}(\mathrm{t}-1)+\mathrm{e}^{*} \mathrm{DIR}(\mathrm{t}-2)$

\begin{tabular}{|c|c|c|c|c|c|c|}
\hline $\mathbf{i}=$ & $\begin{array}{c}\text { b } \\
\text { (P value) } \\
\text { (St. Er.) }\end{array}$ & $\begin{array}{c}\text { c } \\
\text { (P value) } \\
\text { (St. Er.) }\end{array}$ & $\begin{array}{c}\text { d } \\
\text { (P value) } \\
\text { (St. Er.) }\end{array}$ & $\begin{array}{c}\text { e } \\
\text { (P value) } \\
\text { (St. Er.) }\end{array}$ & R sq. & DW \\
\hline 8 & $\begin{array}{l}2.32 \\
0.00 \\
0.46\end{array}$ & $\begin{array}{c}-0.28 \\
0.10 \\
0.16\end{array}$ & $\begin{array}{l}0.02 \\
0.89 \\
0.19\end{array}$ & $\begin{array}{r}-0.17 \\
0.27 \\
0.15\end{array}$ & 0.75 & 2.42 \\
\hline 7 & $\begin{array}{l}1.84 \\
0.00 \\
0.34\end{array}$ & $\begin{array}{l}0.26 \\
0.17 \\
0.18\end{array}$ & $\begin{array}{l}0.14 \\
0.47 \\
0.19\end{array}$ & $\begin{array}{c}-0.28 \\
0.11 \\
0.16\end{array}$ & 0.74 & 2.05 \\
\hline 6 & $\begin{array}{l}1.09 \\
0.00 \\
0.35\end{array}$ & $\begin{array}{l}0.62 \\
0.01 \\
0.23\end{array}$ & $\begin{array}{l}0.15 \\
0.51 \\
0.22\end{array}$ & $\begin{array}{l}-0.17 \\
0.45 \\
0.22\end{array}$ & 0.52 & 1.98 \\
\hline 5 & $\begin{array}{l}0.74 \\
0.02 \\
0.29\end{array}$ & $\begin{array}{l}0.57 \\
0.00 \\
0.17\end{array}$ & $\begin{array}{l}0.09 \\
0.67 \\
0.21\end{array}$ & $\begin{array}{c}-0.03 \\
0.86 \\
0.20\end{array}$ & 0.51 & 1.87 \\
\hline 4 & $\begin{array}{l}0.58 \\
0.05 \\
0.27\end{array}$ & $\begin{array}{l}0.45 \\
0.00 \\
0.13\end{array}$ & $\begin{array}{l}0.12 \\
0.54 \\
0.21\end{array}$ & $\begin{array}{c}-0.05 \\
0.77 \\
0.20\end{array}$ & 0.49 & 1.83 \\
\hline 3 & $\begin{array}{l}0.30 \\
0.24 \\
0.25\end{array}$ & $\begin{array}{l}0.38 \\
0.00 \\
0.12\end{array}$ & $\begin{array}{l}0.15 \\
0.49 \\
0.21\end{array}$ & $\begin{array}{l}0.02 \\
0.90 \\
0.20\end{array}$ & 0.41 & 1.94 \\
\hline 2 & $\begin{array}{l}0.16 \\
0.46 \\
0.22\end{array}$ & $\begin{array}{l}0.41 \\
0.00 \\
0.13\end{array}$ & $\begin{array}{l}0.06 \\
0.78 \\
0.22\end{array}$ & $\begin{array}{l}0.02 \\
0.88 \\
0.19\end{array}$ & 0.40 & 1.86 \\
\hline
\end{tabular}




$\begin{array}{ccccccc}1 & 0.08 & 0.49 & -0.02 & -0.12 & 0.40 & 1.94 \\ & 0.69 & 0.00 & 0.90 & 0.50 & & \\ & 0.21 & 0.15 & 0.23 & 0.18 & & \\ 0 & & & & & & \\ & 0.21 & 0.44 & 0.05 & -0.35 & 0.19 & 2.03 \\ & 0.36 & 0.08 & 0.85 & 0.17 & & \\ & 0.23 & 0.23 & 0.29 & 0.25 & & \\ & & & & & & \\ & 0.21 & 0.29 & 0.27 & -0.23 & 0.09 & \\ & 0.50 & 0.26 & 0.30 & 0.42 & & \\ & 0.31 & 0.25 & 0.26 & 0.28 & & \end{array}$


Table 12: Regression in first differences, no lags (adj. DB)

(ii) $\operatorname{DIR}(\mathrm{t})=\mathrm{b}^{*}(\Pi(\mathrm{t}+\mathrm{i})-2.5)+\mathrm{c}^{*}(\operatorname{GDP}(\mathrm{t}+\mathrm{i})-2.25)$

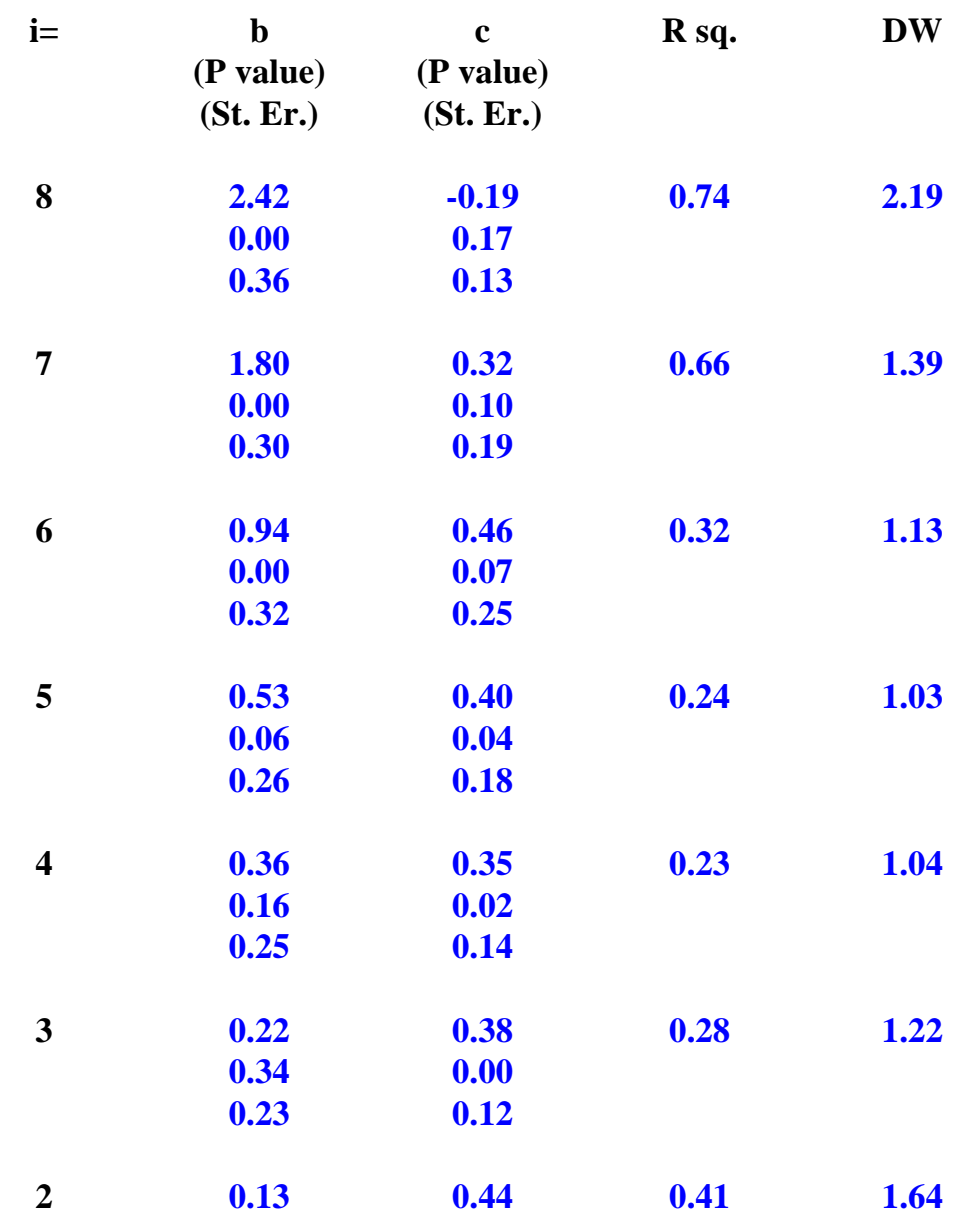




\begin{tabular}{|c|c|c|c|c|}
\hline & 0.52 & 0.00 & & \\
\hline & 0.20 & 0.10 & & \\
\hline 1 & 0.01 & 0.44 & 0.43 & 1.97 \\
\hline & 0.94 & 0.00 & & \\
\hline & 0.20 & 0.10 & & \\
\hline 0 & 0.12 & 0.30 & 0.22 & 1.65 \\
\hline & 0.57 & 0.00 & & \\
\hline & 0.21 & 0.10 & & \\
\hline Actual & 0.10 & $\mathbf{0 . 3 0}$ & 0.18 & 1.39 \\
\hline & 0.61 & 0.01 & & \\
\hline & 0.21 & 0.11 & & \\
\hline
\end{tabular}


Table 13: Regression in levels (unadj. Db)

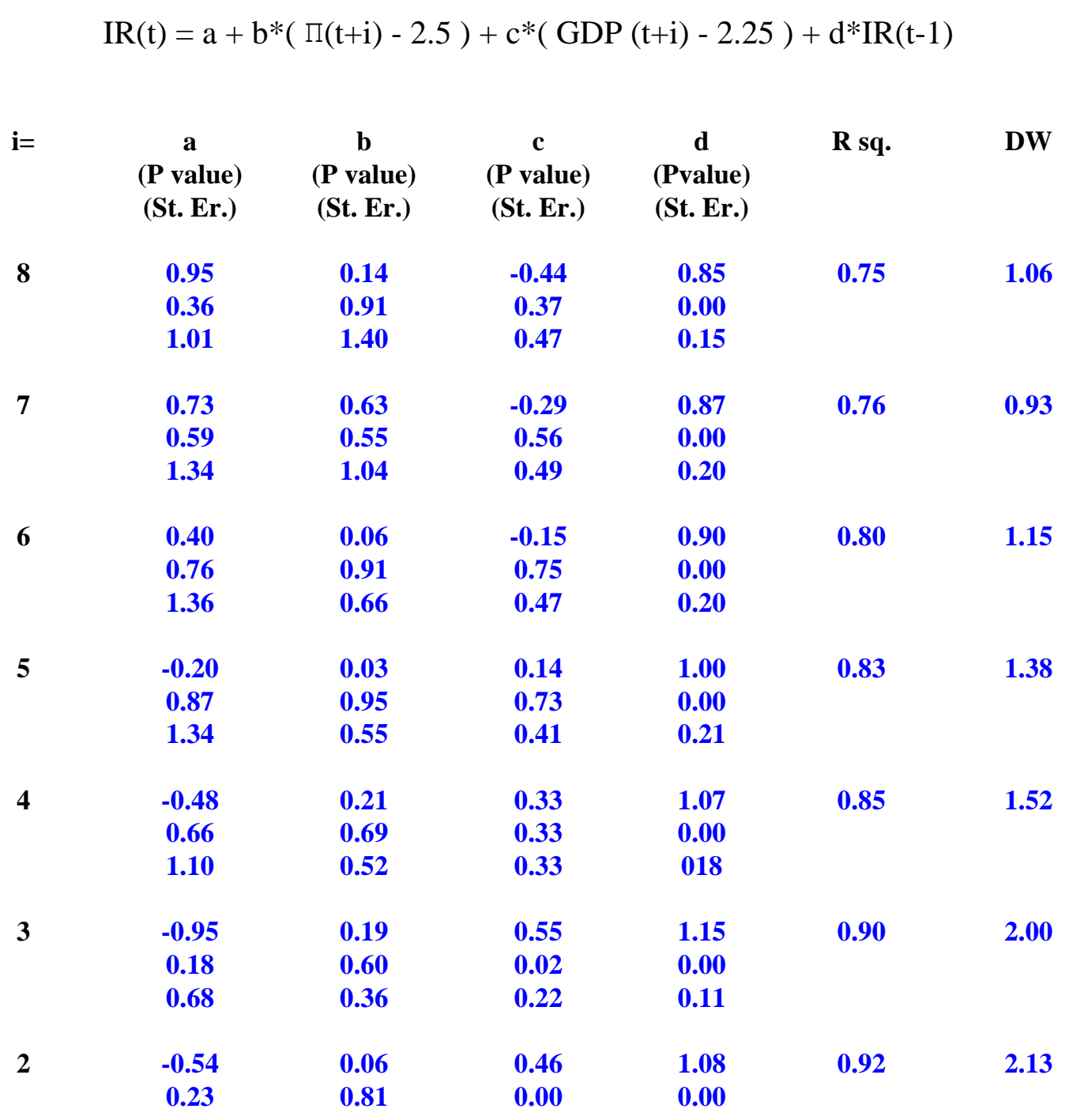




$\begin{array}{ccccccc} & 0.45 & 0.26 & 0.14 & 0.07 & & \\ 1 & 0.01 & -0.09 & 0.37 & 0.97 & 0.92 & 1.94 \\ & 0.96 & 0.71 & 0.00 & 0.00 & & \\ & 0.36 & 0.24 & 0.11 & 0.06 & & \\ 0 & & & & & & \\ & 0.39 & -0.00 & 0.30 & 0.90 & 0.92 & 1.83 \\ & 0.30 & 0.97 & 0.01 & 0.00 & & \\ \text { Actual } & 0.37 & 0.22 & 0.11 & 0.06 & & \\ & 0.57 & -0.02 & 0.46 & 0.85 & 0.93 & 1.88 \\ & 0.12 & 0.90 & 0.00 & 0.00 & & \\ & 0.36 & 0.19 & 0.12 & 0.06 & & \end{array}$


Table 14: Regression in first differences (unadj. DB)

(i) $\quad \operatorname{DIR}(\mathrm{t})=\mathrm{b}^{*}(\Pi(\mathrm{t}+\mathrm{i})-2.5)+\mathrm{c} *(\operatorname{GDP}(\mathrm{t}+\mathrm{i})-2.25)+\mathrm{d}^{*} \operatorname{DIR}(\mathrm{t}-1)+\mathrm{e}^{*} \mathrm{DIR}(\mathrm{t}-2)$

$\mathbf{i}=$

$\begin{array}{cccc}\begin{array}{c}\text { b } \\ \text { (P value })\end{array} & \begin{array}{c}\text { c } \\ \text { (P value) }\end{array} & \begin{array}{c}\text { d } \\ \text { (P value) }\end{array} & \begin{array}{c}\text { e } \\ \text { (P value })\end{array} \\ \text { (St. Er.) } & \text { (St. Er.) } & \text { (St. Er.) } & \text { (St. Er. })\end{array}$

8

$0.13-0.19$

-0.19
0.55

0.51

$-0.28$

$\begin{array}{ll}0.92 & 0.55 \\ 1.51 & 0.32\end{array}$

0.13

0.33

0.27

7

$\begin{array}{ll}0.69 & -0.06\end{array}$

-0.06
0.85

0.52

$-0.25$

$\begin{array}{ll}0.55 & 0.85 \\ 1.14 & 0.36\end{array}$

0.14

0.46

6

0.24

0.15

0.34

0.33

0.72

0.15
0.70

0.43

$-0.12$

0.40

0.17
030

0.70

5

$\begin{array}{ll}0.38 & 0.34\end{array}$

030

0.32

0.41

0.26

0.33

$-0.04$

0.13

2.14

4

0.42

0.35

0.27

0.27

$\begin{array}{ll}0.27 & 0.09 \\ 0.37 & 0.20\end{array}$

0.28

$-0.06$

0.80

3

0.24

0.32

0.25

0.25

$$
\begin{aligned}
& 0.41 \\
& 0.28
\end{aligned}
$$

0.05

0.24

0.00

0.97

2

0.16

0.37

0.24

0.22

0.22

0.50

0.02

0.13
0.59

0.00

0.96

0.29

1.96 


$\begin{array}{ccccccc} & 0.24 & 0.15 & 0.24 & 0.20 & & \\ 1 & 0.08 & 0.46 & 0.02 & -0.12 & 0.32 & 2.00 \\ & 0.69 & 0.01 & 0.93 & 0.51 & & \\ & 0.22 & 0.17 & 0.24 & 0.19 & & \\ & & & & & & \\ & 0.21 & 0.40 & 0.09 & -0.33 & 0.16 & 2.04 \\ & 0.37 & 0.11 & 0.76 & 0.20 & & \\ & 0.23 & 0.24 & 0.30 & 0.25 & & \\ & & & & & & \\ & 0.21 & 0.29 & 0.27 & -0.23 & 0.09 & \\ & 0.50 & 0.26 & 0.30 & 0.42 & & \\ & 0.31 & 0.25 & 0.26 & 0.28 & & \end{array}$


Table 15: Regression in first differences, no lags (unadj. DB)

(iii) $\quad \operatorname{DIR}(\mathrm{t})=\mathrm{b}^{*}(\Pi(\mathrm{t}+\mathrm{i})-2.5)+\mathrm{c}^{*}(\mathrm{GDP}(\mathrm{t}+\mathrm{i})-2.25)$

\begin{tabular}{|c|c|c|c|c|}
\hline$i=$ & $\begin{array}{c}\text { b } \\
\text { (P value) } \\
\text { (St. Er.) }\end{array}$ & $\begin{array}{c}\text { c } \\
\text { (P value) } \\
\text { (St. Er.) }\end{array}$ & R sq. & DW \\
\hline 8 & $\begin{array}{l}0.23 \\
0.87 \\
1.42\end{array}$ & $\begin{array}{c}-0.24 \\
0.39 \\
0.28\end{array}$ & 0.02 & 1.01 \\
\hline 7 & $\begin{array}{l}0.29 \\
0.75 \\
0.93\end{array}$ & $\begin{array}{c}-0.27 \\
0.44 \\
0.34\end{array}$ & 0.01 & 0.90 \\
\hline 6 & $\begin{array}{l}0.08 \\
0.86 \\
0.49\end{array}$ & $\begin{array}{c}-0.16 \\
0.64 \\
0.33\end{array}$ & -0.03 & 1.07 \\
\hline 5 & $\begin{array}{l}0.14 \\
0.68 \\
0.34\end{array}$ & $\begin{array}{l}0.06 \\
0.78 \\
0.24\end{array}$ & -0.04 & 1.09 \\
\hline 4 & $\begin{array}{l}0.17 \\
0.56 \\
0.29\end{array}$ & $\begin{array}{l}0.17 \\
0.35 \\
0.18\end{array}$ & 0.00 & 1.11 \\
\hline 3 & $\begin{array}{l}0.15 \\
0.55 \\
0.26\end{array}$ & $\begin{array}{l}0.30 \\
0.06 \\
0.15\end{array}$ & 0.11 & 1.24 \\
\hline
\end{tabular}




\begin{tabular}{|c|c|c|c|c|}
\hline \multirow[t]{3}{*}{2} & 0.13 & 0.42 & \multirow[t]{3}{*}{$\mathbf{0 . 3 0}$} & \multirow[t]{3}{*}{1.61} \\
\hline & 0.54 & 0.00 & & \\
\hline & 0.21 & 0.13 & & \\
\hline \multirow[t]{3}{*}{1} & 0.02 & 0.43 & \multirow[t]{3}{*}{0.37} & \multirow[t]{3}{*}{1.94} \\
\hline & 0.92 & 0.00 & & \\
\hline & 0.21 & 0.11 & & \\
\hline \multirow[t]{3}{*}{ 0 } & 0.12 & 0.29 & \multirow[t]{3}{*}{0.21} & \multirow[t]{3}{*}{1.64} \\
\hline & 0.56 & 0.01 & & \\
\hline & 0.21 & 0.10 & & \\
\hline \multirow[t]{3}{*}{ Actual } & 0.10 & 0.30 & \multirow[t]{3}{*}{0.18} & \multirow[t]{3}{*}{1.39} \\
\hline & 0.61 & 0.01 & & \\
\hline & 0.21 & 0.11 & & \\
\hline
\end{tabular}

